\title{
A Geocybernetic Analysis of the Principles of the Extractive Industries Transparency Initiative (EITI)
}

\author{
Jason Phillips \\ Institute FORWARD - For Worldwide Alternative Research and Development \\ Edificio Parque Los Alpes, Calle 31E Transversal 71D, C103, Los Alpes, 130005, Cartagena de Indias, \\ Colombia \\ E-mail: jp1@tiscali.co.uk
}

\section{Kai Whiting}

MARETEC, Department of Mechanical Engineering, Instituto Superior Técnico, Universidade de Lisboa, Portugal Institute FORWARD - For Worldwide Alternative Research and Development Edificio Parque Los Alpes, Calle 31E Transversal 71D, C103, Los Alpes, 130005, Cartagena de Indias, Colombia

E-mail: whitingke@yahoo.co.uk

Correspondence Address of Author:

Kai Whiting
MARETEC, Department of Mechanical Engineering, Instituto Superior Técnico, Universidade de Lisboa,
Portugal
E-mail: whitingke@yahoo.co.uk

\section{Abstract}

Evaluations concerning the EITI's strategic contribution to sustainable development are extremely sparse to say the least. When such evaluations do occur, they use qualitative frameworks in determining sustainability outcomes. This has led to the use of reductionist and/or anthropocentric perspectives, such as the Brundtland Commission's definition of sustainable development. This fundamentally contradicts developments in sustainability science, which have strongly advocated the management of the coupled dynamic environment-human relationship at all spatialtemporal scales. Therefore, a quantitative-based evaluation of the EITI's contribution towards sustainable development, using a consistent holistic approach, represents a fundamental knowledge gap within the current literature. In order to address this knowledge gap, this paper conducts such an evaluation by using a new sustainability 
assessment tool called the Geocybernetic Assessment Matrix (GAM). The GAM applies the fundamental and complex paradigms found within geocybernetic theory through a semi-quantitative matrix approach. The GAM evaluates the 12 principles of the EITI framework in order to determine their contribution towards sustainable development. The results indicate that the EITI is strongly anthropocentric in nature, and does not significantly contribute towards sustainable development of national resource wealth. Furthermore, they indicate that the EITI is flawed in conception and implementation concerning how it contributes towards sustainable development. This is demonstrated by the EITI having no clear statement or commitment as to the need to maintain environmental resources or services for present or future generations. Therefore, there are legimate questions as to the actual value and capabilities of the EITI - both as a tool for the transparent and accountable management of national resource wealth, and as a means of contributing towards sustainable development.

Keywords: Sustainable Development; Quantitative Strategic Assessment; Natural Resources; Resource Curse; Resource Management; Environmental Governance. 


\section{Introduction}

One of the fundamental features of the 21 st century is the continuing use of scarce natural resources in the development of national economies and a globalised society. Whilst natural resource exports continue to be very significant for some developed countries such as Australia, Canada, and Norway, most natural resource exporters are located in economically developing countries. This implies that mineral resources are likely to constitute an even greater share of many countries' exports and national income in the near future (Clark, 2011; WTO, 2014). This is potentially problematic given that various developing economies have experienced a range of negative consequences, in trying to finance national economic progress via natural resource commodities. These consequences have included violent conflicts, environmental degradation and the displacement of indigenous communities and skills (based on UNDP, 2012, 2015). Therefore, the presence of natural resource wealth can and does provide a significant mechanism for corruption, heightened inequalities and undermined democratic governance (based on UNDP, 2012, 2015). Furthermore, the presence of ineffective public institutions means that in some cases, resource rich countries may actually grow at a slower rate than their resource poor counterparts. Many developing countries with abundant natural resources are hampered by a lack of transparency and accountability mechanisms, along with poor public sector capacity. In order to try to counter the problems highlighted, a global standard called the Extractive Industries Transparency Initiative (EITI) was developed. 


\subsection{Extractive Industries Transparency Initiative}

The EITI was founded in 2003 on the idea that the "prudent use of natural resource wealth should be an important engine for sustainable growth that contributes to sustainable development and public poverty reduction" (Short, 2014). Its aim is "to promote open and accountable management of natural resources" (EITI, 2015b). This was expanded into 12 fundamental EITI principles, designed to develop and maintain the transparent management of natural resources (see: Appendix - Table A1).

The 12 principles are implemented via a participatory and collaborative approach between the government, private sectors and civil society organisations. This is achieved by: (i). the strengthening of government and private sector systems; (ii). the development of open public debate; and (iii). the building of trust through a tripartite coalition of State, the private sector and civil society (EITI, 2015b). The tripartite committee, formed as part of the EITI process, is made up of individuals from various government entities, private sector and members of civil society. The stated benefits of the EITI for member States are three-fold: (i). strengthened governance; (ii). a level-playing field; and (iii). reliable and accessible information (EITI, 2015d). The EITI is therefore intended to ensure a fairer and more transparent accounting process for the exploitation of natural resources.

Up to May 2015, 48 countries were implementing the revised 2013 EITI Standard. Of these, 31 countries were considered to be "EITI Compliant", whilst the others, such as the United Kingdom and Colombia (who both joined in October 2014), were considered as candidates for membership. (EITI, 2015c). Five countries have had 
their membership temporarily suspended. Up to April 2015, 1.6 trillion dollars (USD) of government revenues (royalties, taxes and other payments) generated from natural resource exploitation have been disclosed as part of the EITI initiative (EITI, 2015d).

\subsection{Background and Context of Paper}

\subsubsection{Overview}

According to Cabezas (2014), perhaps the most compelling argument for public disclosure initiatives, such as the EITI, is that transparency should be a prerequisite for market and consumer access and State infrastructure. This is because the private mining sector obtains support, and thus by extension profits financially, from the public institutions that provided education to its workers, constructed the roads that connects their operations to the market, and protects operations from rogue activity in the courts of law. Consequently, any argument which is put forward by a mining corporation as to weakened economic efficiency and privacy concerns is secondary to the primary overriding issues of accountability and balancing rights between all that participate in the global market (based on Cabezas, 2014).

Public accountability disclosures initiatives, such as the EITI, should and must focus on the provision of information on topics such as clean water, air quality and poverty reduction. In addition, and worthy of note, the EITI should not be established in such a way where unhelpful judgements overshadow the processes for greater transparency and public debate. 
Transparency provides the mechanism for this to happen, and should ensure that those affected by the extractive industry can voice their concerns. Furthermore, it collectively prohibits, or at a minimum allows for open discussion of, corporate decisions where they perceived as harmful to future sustainable development. The nature of sustainability indicators differs with use and application, e.g. a product life cycle analysis, or a formal system to reduce global greenhouse gas emissions. Some, such as the GAM developed within this paper, emphasise quantitative based measures, whilst others lean towards more qualitative or Environmental Impact Assessmentbased methodologies.

Arguably the most significant problem is that there no widely accepted framework for selecting goal-relevant and/or contextually meaningful indicators. According to Dale et al. $(2015, \mathrm{p} 4)$ this issue "stems not from the absence of effective indicators per se but from the lack of a deliberative process for translating sustainability goals and assessment objectives into practical, cost-effective, and useful indicators to guide planning and decisions at a variety of scales". Likewise, context is an important aspect required to successfully prioritise sustainability indicators. This is because it entails identifying the socio-economic, cultural, institutional, political, and regulatory environments, and their spatial-temporal scope. The failure to frame a particular situation in this way can result in unintended biases in the selection of indicators (Dale et al., 2015). 


\subsubsection{Importance of Good Governance and Public Disclosure}

Poor fund governance can result in the loss of billions of dollars in oil, gas and mineral sales. For instance, due to excessive risk-taking and lack of oversight, the Libyan Investment Authority lost much of a $\$ 1.2$ billion investment in equity and currency derivatives following the 2008 global financial crisis (Revenue Watch Institute, 2014). And yet, if good governance is combined with transparent public disclosure, then mineral discoveries are potentially transformational to a country.

However despite this fact, only 10 of the 58 countries examined in the Revenue Governance Index, in 2013, published the majority of their oil, gas and mineral contracts and licensing agreements (Natural Resource Governance Institute, 2013). This is of particular concern for those countries that remain heavily dependent on oil, gas and mineral revenue. Whilst the total global revenue for the extractive industry remains unknown, for some EITI compliant countries the percentage of government revenue derived from the extractive industry is over 90 percent (see: Figure 1).

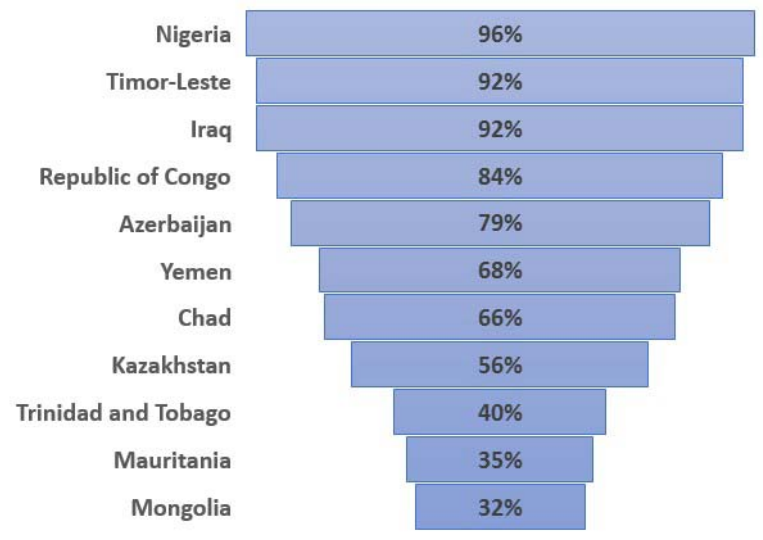

Figure 1 Percentage of government revenue from extractive industry, adapted from EITI (2015e) 
The Simandou iron ore project in Guinea and iron ore and petroleum projects in Liberia, for example, are expected to generate annual revenues of $\$ 1.6$ billion (USD) in each country respectively. This represents 31 percent and 147 percent of their respective 2011 national GDP (Africa Progress Panel, 2013, p45).

\subsubsection{Other Sustainability Indicators within Mining}

The EITI is not the only global initiative focused on public disclosure and transparency within the extractive sector. Other important ones are from the Global Reporting Initiative, G4 Mining and Metals Sectors Disclosures within the G4 supplement, and the Mining Association of Canada's (MAC) Towards Sustainable Mining Commitment programme (Jarvie-Eggart, 2015). The latter programme is mandatory for Canadian operations and its use is encouraged for operations by its members on sites worldwide. MAC's commitment is, as with the EITI and the widely known Global Reporting Initiative (GRI), based on a set of guiding principles. They are established upon a suite of six performance protocols involving 23 indicators that mining companies measure and publicly report their performance against (Mining Association of Canada, 2016). A letter grade is assigned based on meeting MAC standards and performance criteria.

The GRI reporting system, whilst promoting transparency, differs from the EITI and MAC in that a company may select which, and how many, of the GRI indicators they will report. They are under are no obligation to report on all of them. This can create significant asymmetries in the information collected and disclosures made. Furthermore, "sustainability" scores indicate how much information a company is 
reporting to the public. As Jarvie-Eggart (2015) however argues, they do not represent how well a given company is doing at fulfilling a particular indicator and cannot be easily compared.

\subsection{Purpose of Paper}

There is abundant literature on the EITI evaluating its performance at the national level (e.g. Aaronson, 2011; Hilson, 2014; Leventon et al. 2015; Shroder, 2015; Sovacool and Andrews, 2015; Sturesson and Zobel, 2015). However, literature is extremely sparse in relation to the EITI's strategic contribution in orientating a country towards sustainable development (e.g. Wilson \& Van Alstine, 2014).

The limited amount of literature is arguably because of the tendency to lean towards qualitative case-specific or subject specific approaches (e.g. carbon footprint, ecological well-being), as well as the narrowing of the term 'sustainability' towards the sentiment expressed in the Brundtland report (re: WCED, 1987). This has resulted in the adoption of a strong anthropocentric perspective of sustainability when applying assessment tools. This fundamentally contradicts Dearing et al. (2014), Lovelock (1988), Lucht (2010), Phillips (2010a), Rockström et al. (2009), and Schellnhuber (1998) amongst others, who have strongly advocated for the assessment and/or management of a coupled dynamic relationship between the environment and humanity, at all spatial-temporal scales. The use of a qualitative approach has also led to reductionist perspectives of sustainable development being adopted, as in the case of Wilson and Van Alstine (2014). 
The sole use of the qualitative approach is therefore not the most appropriate way to assess whether or not the EITI is assisting sustainable development / sustainability. Consequently, there is a need for a quantitative-based assessment of the EITI. This would introduce a strong element of rigor and transparency within a strategic evaluation of the EITI. Such an assessment would mean the assessor(s) having to objectively and critically justify the valuation of parameters. Furthermore, it would require the assessor(s) to have to clearly justify the determined implications and outcomes derived from the final obtained scores. The absence of a consistent holistic quantitative-based evaluation of the EITI represents a fundamental gap of knowledge within the current literature.

\subsection{Objective and Structure of Paper}

This paper presents a strategic evaluation of the EITI's 12 principles, to determine the level and nature of its contribution to sustainability at the national level. Specifically, the authors intend to evaluate the EITI's approach to the management of natural resource wealth as a means of contributing towards a country's development (see: Appendix - Table A1). This will be achieved through the application of a new sustainability assessment tool called the Geocybernetic Assessment Matrix (GAM) (re: Phillips, 2016).

In order to meet the intended aim, the paper is organised as follows. Section 2 outlines the GAM, in respect to its conceptual framework and the methodology. Section 3 presents and discusses the results of the GAM application to the 12 principles of the EITI. Section 4 discusses the context and implications of the results, and evaluates the 
EITI Principles 1 and 2 from a geocybernetic perspective. Finally, section 5 presents the paper's final conclusions, and the Appendix provides Tables A1-A6.

\section{Methodology}

\subsection{Overview}

The Geocybernetic Assessment Matrix (GAM) is a new sustainability assessment tool, first described in Phillips (2016). It evaluates the level and nature of sustainability and/or unsustainability occurring, in relation to some, or all, of the five fundamental and complex geocybernetic paradigms, as first proposed by Schellnhuber (1998). The GAM is based upon the Rapid Impact Assessment Matrix (RIAM) (Pastakia, 1998; Pastakia and Jensen, 1998), which has become a respected method used in the Environmental Impact Assessment (EIA). The GAM can be scaled to various levels, including project, policy and legal frameworks (regulations, directives, legislation etc.). It can also be applied to management strategies / tools and indicators. This was demonstrated in Phillips (2016) which applied the GAM to evaluate Part 1 of the UK Climate Change Act (2008) (Great Britain, 2008).

The GAM uses semi-quantitative values for each designated or chosen parameter evaluated, in relation to the three pillars of sustainable development - environmental, social and economic. The fundamental geocybernetic paradigms are assessed on an individual basis, following a scoping stage.

In order to better understand the GAM and its application, the next sub-section provides a brief discussion of the key conceptual aspects of Geocybernetics. 


\subsection{Geocybernetics}

Geocybernetics is concerned with the development and management of the coupled dynamic co-evolutionary relationship over time between the environment and humanity (Schellnhuber, 1999; Schellnhuber and Kropp, 1998). The purpose of geocybernetics is to ensure that humans continue to live and survive on the planet, at all spatial-temporal scales, through the prudent and effective use of planetary resources (Phillips, 2016).

The designated pathway for sustainable development and its outcome take place within a multi-dimensional 'state space'. This 'state space' is where all potential values of the variables, which determine the outcomes for the environment and human society, can occur (Phillips, 2016). Within this 'state space', also referred to as 'coevolutionary space', there are two fundamental zones, as highlighted by Schellnhuber (1998, 1999, 2001), Schellnhuber and Kropp (1998), Gallopin (2003), Lucht (2010), and Phillips (2010, 2016):

1. Catastrophic domains - These domains are two-fold: (i) areas where humans are able to survive, but below a tolerable socio-economic level (e.g. faminestricken areas of South Sudan or Ethiopia); and (ii) areas that are outside the thresholds that support human life - i.e. those conditions that typically follow a natural catastrophe or profound changes in the environment (e.g. at the most extreme on a planetary scale - the proposed 'Snowball Earth' hypothesis). 
2. Inaccessible regions - This is a 'void' within co-evolutionary space by which a designated co-evolutionary pathway will never be able to enter, either impulsively or intentionally, from a determined starting point.

The potential pathways and their outcomes in co-evolutionary space, in a highly simplified form, were illustrated by Lucht (2010) (see: Figure 2), who also highlighted the fundamental zones described.

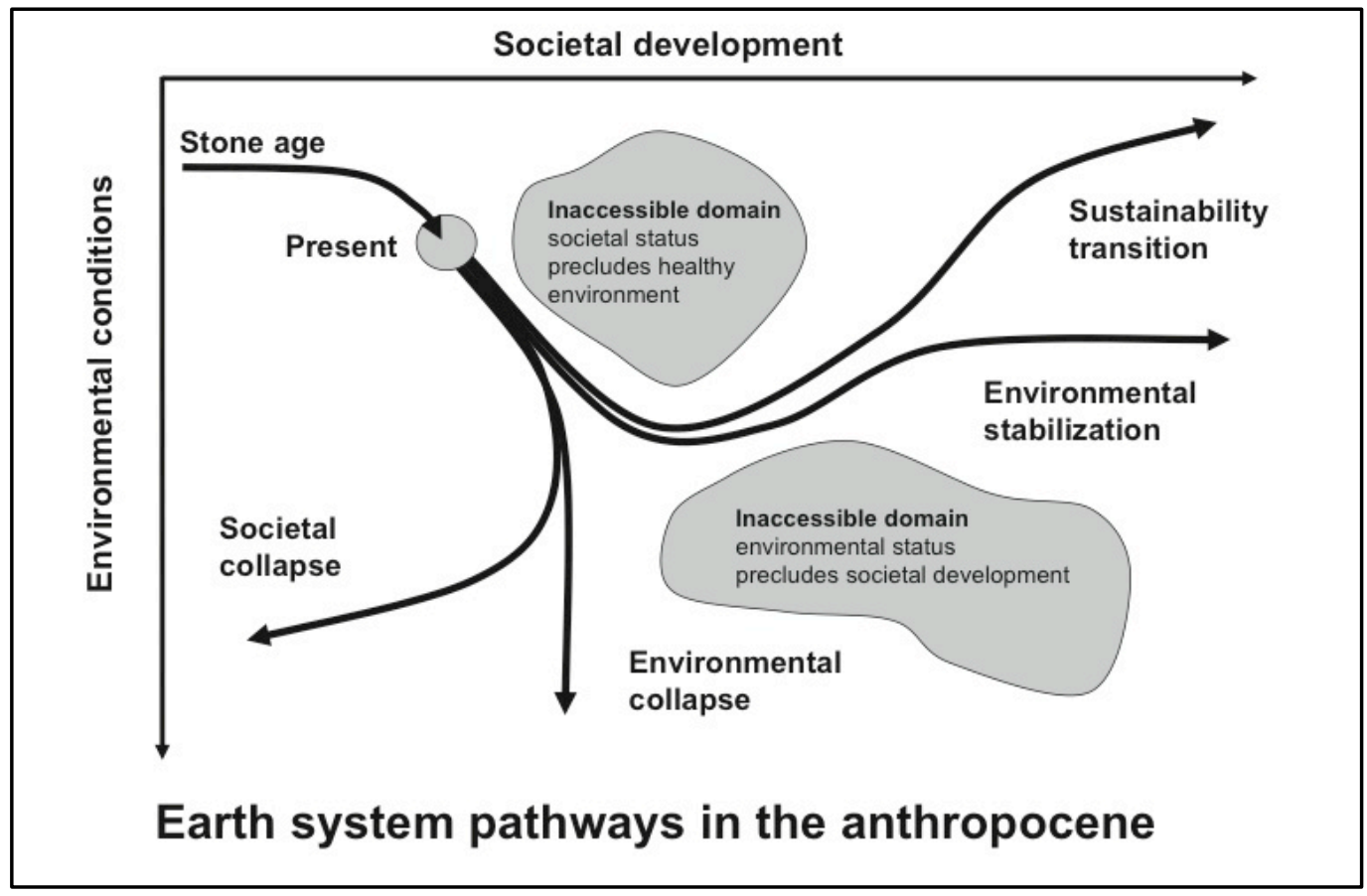

Figure 2 A simplified representation of the pathways of strategies aimed at the coevolution of the environment-human system and relationship, by Lucht (2010, Figure 2, p21) based on Schellnhuber (1999). Reproduced with very kind permission by W. Lucht. 
A co-evolutionary pathway by which a designated strategy for sustainable development can occur, is in the form of paradigms (Schellnhuber, 1998; Schellnhuber and Kropp, 1998, Phillips, 2016). Five fundamental geocybernetic paradigms of sustainable development were defined by Schellnhuber (1998), whereby all notions, theories, strategies, policies etc of sustainability, can be categorised (see: Table 1). There is a further geocybernetic paradigm called a complex paradigm. This is where two, or more, of the five fundamental paradigms exist within the same designated co-evolutionary pathway. For example, Optimization and Stabilization may co-exist within the same strategic framework for achieving and managing sustainable development. 
Table 1 The five fundamental and complex geocybernetic paradigms of sustainable development, based on Schellnhuber (1998, 1999, 2001), Schellnhuber and Kropp (1998) and Gallopin (2003).

\begin{tabular}{|c|c|c|c|c|}
\hline Notation & Paradigm & Description & $\begin{array}{c}\text { Positive } \\
\text { Goal }\end{array}$ & $\begin{array}{c}\text { Negative } \\
\text { Motive }\end{array}$ \\
\hline$\rho_{0}$ & Standardization & $\begin{array}{l}\text { The application of sustainable development via instruments } \\
\text { such as sustainability indicators. The co-evolutionary path of the } \\
\text { environment-human system is considered to be correct, if the } \\
\text { values of the indicators occur within the 'safe range' limits of } \\
\text { the system. }\end{array}$ & Order & Despotism \\
\hline$\rho_{1}$ & Optimization & $\begin{array}{l}\text { Concerned with the obtainment of the "best" design for the } \\
\text { environment-human system. This is achieved by choosing the } \\
\text { optimal path for co-evolution over a fixed period of time. }\end{array}$ & Prosperity & Greed \\
\hline$\rho_{2}$ & Pessimization & $\begin{array}{l}\text { Undertaking the smallest amount of damage for the maximum } \\
\text { amount of potential benefit - the precautionary principle. It is } \\
\text { therefore the least speculative and most essential for the } \\
\text { development of a set of minimum standards for the safe } \\
\text { operation of the Earth system. }\end{array}$ & Security & Cowardice \\
\hline$\rho_{3}$ & Equitization & $\begin{array}{l}\text { In essence, the Brundtland notion - the preservation of options } \\
\text { for future generations. Therefore, the notion of "equity" is } \\
\text { associated with environmental and developmental options for } \\
\text { future generations. }\end{array}$ & Fairness & Jaundice \\
\hline$\rho_{4}$ & Stabilization & $\begin{array}{l}\text { Bringing the environment-human system into a desirable state } \\
\text { of co-evolution, and then maintaining it through the use of good } \\
\text { management. }\end{array}$ & Reliability & Indolence \\
\hline- & Complex & $\begin{array}{l}\text { This is where two of more of the five fundamental exist within } \\
\text { the specified management strategy for the environment-human } \\
\text { relationship, over a designated time period. }\end{array}$ & - & - \\
\hline
\end{tabular}

\subsection{Geocybernetic Assessment Matrix (GAM)}

\subsubsection{Scoping}

Scoping in the GAM is concerned with which fundamental geocybernetic paradigm(s) are present within each parameter evaluated. To determine whether or not the paradigm(s) is present, a simple checklist approach is used, as demonstrated in Table

4. 


\subsubsection{Assessment Criteria}

The assessment criteria for the GAM are divided into two groups, as stated by Phillips (2016):

(1) Criteria A - Determines the importance and nature of effects of the parameter in regards to the paradigm being evaluated.

(2) Criteria B - Determines the spatial and temporal effects of the parameter within the context of the paradigm being evaluated.

Criteria A evaluate the paradigm's significance, magnitude and nature of conformity in respect to the parameter being evaluated. The purpose of these criteria is to determine the degree of which the paradigm is evident. To give an example, with respect to the environmental dimension, to what extent does the principle being evaluated meet the stated parameters of Optimization in terms of significance (Criteria A1). In simpler parlance, the degree to which a principle conforms to meeting and achieving the stated goals and outcomes of the paradigm, in obtaining the best pathway towards sustainable development environmentally, and over what geographical scale(s) and time frame.

Criteria B evaluate the parameter's spatial and temporal effects with respect to the paradigm. Its purpose is to evaluate whether a parameter will have positive or negative effects in relation to: (i) time scale (short, medium, or long-term); and (ii). geographical scale (local, regional, national, international, global). For example, when considering the Optimization paradigm for a given parameter, it may be prudent to 
consider whether or not a certain strategic commitment for mineral wealth management leads to the optimal pathway towards sustainable development. Specifically, it is concerned with whether or not the selected parameter provides future generations with a viable environment and an improved, or at least an identical, standard of living.

The criteria scores evaluated are based upon the objective and critical judgment of an assessor(s), with respect to both the primary and/or secondary data available. The assessment criteria are shown in Table 2 . 
Table 2 Assessment Criteria for GAM (after Phillips, 2016).

\begin{tabular}{|c|c|c|}
\hline Criterion & Scale & Description \\
\hline \multirow{4}{*}{ A1: Significance of Paradigm } & 3 & High significance \\
\hline & 2 & Moderate significance \\
\hline & 1 & Minor significance \\
\hline & 0 & Non-applicable / non existent \\
\hline \multirow{3}{*}{ A2: Magnitude of Paradigm Conformity } & 3 & Conforms to strong degree \\
\hline & 2 & Conforms to moderate degree \\
\hline & 1 & Conforms to minor / no degree \\
\hline \multirow{7}{*}{ A3: Nature of Impacts } & +3 & Major Positive \\
\hline & +2 & Moderate Positive \\
\hline & +1 & Minor Positive \\
\hline & 0 & No Impact \\
\hline & -1 & Minor Negative \\
\hline & -2 & Moderate Negative \\
\hline & -3 & Major Negative \\
\hline \multirow{5}{*}{ B1: Spatial Impacts } & 5 & National to International Impacts \\
\hline & 4 & Regional to National Impacts \\
\hline & 3 & Local and Outside Vicinity \\
\hline & 2 & Local only \\
\hline & 1 & No Impact / Non-applicable \\
\hline \multirow{4}{*}{ B2: Temporal Impacts } & 4 & Long-term (> 10 years) \\
\hline & 3 & Medium-term (6-10 years) \\
\hline & 2 & Short-term (0-5 years) \\
\hline & 1 & No Impact / Non-applicable \\
\hline
\end{tabular}




\subsubsection{Geocybernetic Score}

\subsubsection{Obtaining GS(E), GS(S) and $\mathrm{GS}(\mathrm{Ec})$}

The assessed criteria scores are used to produce a parameter total for each pillar of sustainability. This is referred to as a 'geocybernetic score' (GS) and is comprised of: GS(E) - environmental geocybernetic score; GS(S) - social geocybernetic score; and GS(Ec) - economic geocybernetic score. These scores reflect the geocybernetic strengths or weaknesses of the parameters, in respect to each pillar of sustainability. The geocybernetic score (GS) for each assessed parameter with respect to GS(E), $\mathrm{GS}(\mathrm{S})$ and $\mathrm{GS}(\mathrm{Ec})$ is obtained using Equations 1-3:

$$
\begin{aligned}
& \mathrm{A} 1 \times \mathrm{A} 2 \times \mathrm{A} 3=\mathrm{A}(\mathrm{T}) \\
& \mathrm{B} 1+\mathrm{B} 2=\mathrm{B}(\mathrm{T}) \\
& \mathrm{A}(\mathrm{T}) \times \mathrm{B}(\mathrm{T})=\mathrm{GS}(x)
\end{aligned}
$$

where:

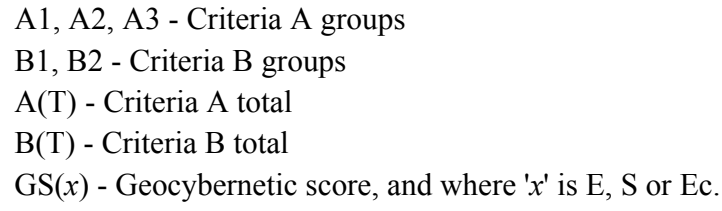

Criteria A groups are the weighting component of each score and therefore are multiplied together, whilst the Criteria B groups are added together to ensure that no influence of the overall geocybernetic score can occur (based on Phillips, 2016).

Based on the criteria scores, shown in Table 2 and Equations 1-3, the potential obtained parameter value of GS for E, S, and Ec occurs within the range- $243 \leq$ $\mathrm{GS}(x) \leq+243$, reflecting the maximum positive and negative GS(x) values obtainable. 


\subsubsection{Obtaining GS(A)}

GS(A) is the total geocybernetic score for a parameter reflecting the anthropospheric components, comprising of the GS(S) and GS(Ec) totals (Phillips, 2016). The need for determining GS(A) arises from the fact that in geocybernetic theory, sustainability is concerned with the nature and level of the co-evolutionary relationship between the ecosphere (environment) and anthroposphere (human society and actions) (Phillips, 2016). The obtained GS(A) value for a parameter is determined as follows:

$$
\mathrm{GS}(\mathrm{A})=\frac{\mathrm{GS}(\mathrm{S})+\mathrm{GS}(\mathrm{Ec})}{2}
$$

The GS(A) still conforms to the value range of $-243 \leq \mathrm{GS}(x) \leq+243$. Where there is a determined value for GS(A) with a decimal point, this value is rounded to the nearest whole number.

\subsubsection{Obtaining GS(T) Score and Range}

$\mathrm{GS}(\mathrm{T})$ is the total geocybernetic score for a parameter and comprises of the obtained parameter values of GS(E) and GS(A):

$$
\mathrm{GS}(\mathrm{T})=\mathrm{GS}(\mathrm{E})+\mathrm{GS}(\mathrm{A})
$$

The obtained value range of GS(T) occurs within the range of $486 \leq \mathrm{GS}(\mathrm{T}) \leq+486$.

The indicated level of sustainability or unsustainability for GS(E), GS(S), GS(Ec), GS(A) and GS(T) is obtained using Table 3. 
Table 3 The GAM Range Bands. a) the range bands for GS(E), GS(S), GS(Ec) and GS(A); and b) the range bands for GS(T) (after Phillips, 2016).

a)

\begin{tabular}{rcl}
\hline GS Score & GS Range Bands & \multicolumn{1}{c}{ Description of GS Range Bands } \\
\hline+183 to +243 & + VS & Very Strong Sustainability \\
+122 to +182 & $+\mathrm{S}$ & Strong Sustainability \\
+61 to +121 & $+\mathrm{W}$ & Weak Sustainability \\
+1 to +60 & $+\mathrm{VW}$ & Very Weak Sustainability \\
0 to -60 & $-\mathrm{VW}$ & Very Weak Unsustainability \\
-61 to -120 & $-\mathrm{W}$ & Weak Unsustainability \\
-121 to -182 & $-\mathrm{S}$ & Strong Unsustainability \\
-183 to -243 & $-\mathrm{VS}$ & Very Strong Unsustainability \\
\hline
\end{tabular}

b)

\begin{tabular}{rcl}
\hline GS Score & GS Range Bands & \multicolumn{1}{c}{ Description of GS Range Bands } \\
\hline+365 to +486 & + VS & Very Strong Sustainability \\
+243 to +364 & $+\mathrm{S}$ & Strong Sustainability \\
+122 to +242 & $+\mathrm{W}$ & Weak Sustainability \\
+1 to +121 & $+\mathrm{VW}$ & Very Weak Sustainability \\
0 to -121 & $-\mathrm{VW}$ & Very Weak Unsustainability \\
-122 to -242 & $-\mathrm{W}$ & Weak Unsustainability \\
-243 to -364 & $-\mathrm{S}$ & Strong Unsustainability \\
-365 to -486 & $-\mathrm{VS}$ & Very Strong Unsustainability \\
\hline
\end{tabular}

The assessment concludes by obtaining two mean average GS(T) values and ranges, as stated by Phillips (2016):

1). $\sum \mathrm{GS}(\overline{\mathrm{T}}) \rho_{\mathrm{x}}$ - The overall paradigm mean average of $G S(T)$ : This simply involves adding all of the GS(T) values obtained for a fundamental paradigm and dividing it by the number of parameters evaluated (see: Equation 6); and 
2). $\sum \mathrm{GS}(\overline{\mathrm{T}}) \rho$ - The overall total mean average of $G S(T)$ : This is the overall paradigm mean average GS(T) scores added together and divided by the number of paradigms evaluated. This value represents the indicated level and nature of sustainability or unsustainability, occurring with respect to the complex paradigm (see: Equation 7).

Based on Phillips (2016), and with reference to the paradigm notation in Table 1, the two mean average GS(T) scores are expressed mathematically as follows:

$$
\begin{gathered}
\mathrm{GS}(\overline{\mathrm{T}}) \rho_{x}=\frac{\sum \mathrm{GS}(\mathrm{T})}{n} \\
\sum \mathrm{GS}(\overline{\mathrm{T}}) \rho=\frac{\mathrm{GS}(\overline{\mathrm{T}}) \rho_{x}+\mathrm{GS}(\overline{\mathrm{T}}) \rho_{x}+\ldots \mathrm{GS}(\overline{\mathrm{T}}) \rho_{x}}{N_{\rho}}
\end{gathered}
$$

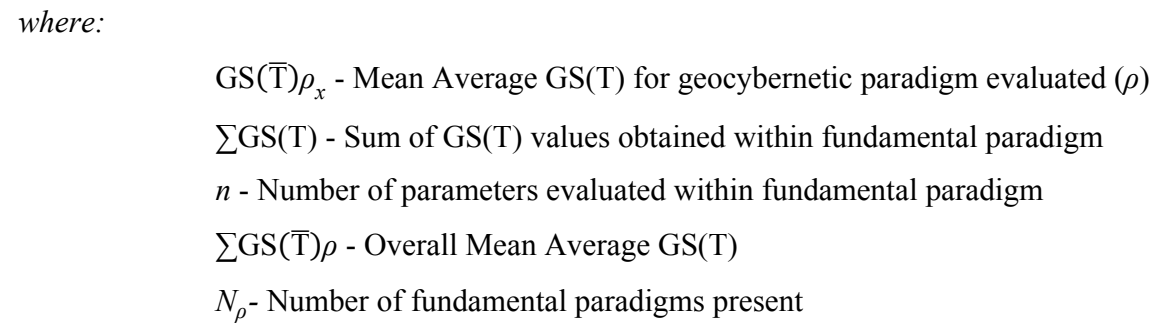

In respect to the mean average of GS(T) for a geocybernetic paradigm $\left(\mathrm{GS}(\overline{\mathrm{T}}) \rho_{x}\right)$, an example of the mathematical notation used is as follows: If the mean average GS(T) for Optimization $\left(\rho_{1}\right)$ is being determined, then it is denoted as $\operatorname{GS}(\overline{\mathrm{T}}) \rho_{1}$; whilst if the mean average $\operatorname{GS}(\mathrm{T})$ for Equitization $\left(\rho_{3}\right)$ is being determined, it is denoted as $\mathrm{GS}(\overline{\mathrm{T}}) \rho_{3}$. The paradigm notation in the form $\rho_{x}$ is based on those provided in Table 1. 


\subsection{Applying the GAM}

The evaluation of the EITI using the GAM methodology involved a four-stage approach. Stage 1 was a detailed literature review of the EITI's strategic framework and methodology for implementation. This review was based on the wide range of documents available on the EITI website (www.eiti.org). In addition, country reports were also examined, in order to provide a detailed understanding and context of the implementation and management of the EITI at the national level. This stage therefore provided the necessary knowledge and understanding concerning how the 12 principles of the EITI are perceived and implemented.

Stage 2 applied the GAM methodology, as described in Section 2.3, to the 12 EITI principles. In order to determine the Criteria $\mathrm{A}$ and $\mathrm{B}$ scores for the principles, in relation to the fundamental geocybernetic paradigms, an extensive knowledge and understanding of geocybernetic and sustainability science theory and practice was drawn upon. This knowledge was taken from Schellnhuber (1998, 1999, 2001); Schellnhuber and Kropp (1998); Lovelock (1988); Gallopin (2003); Rockström et al. (2009a, 2009b); Dearing et al. (2014); Petschel-Held et al. (1999); Eisenack and Kropp (2001); Kropp et al. (2006); Lucht (2010); Costanza et al. (2007); and Phillips (2010a, 2010b, 2011, 2012, 2016). Based upon this body of literature, as well as the detailed review of EITI documentation carried out in Stage 1, scoping and criteria scoring were performed. The scoping and evaluation of criteria scores comprised of an objective determination of the level of conformity of the EITI principles in relation to the five fundamental geocybernetic paradigms. Criteria scores were determined using a conservative approach by evaluating the minimum level of compliance of the 
parameter (the EITI principle), in relation to the stated theory and description of the fundamental paradigm under consideration. This approach was undertaken in order to minimise any potential subjectivity and bias.

Stage 3 involved the re-evaluation of the EITI principles' criteria scores. The purpose of this was to improve accuracy and further reduce any subjectivity and bias. This stage adopted the same conservative approach to criteria scoring conducted in Stage 2. The original and re-evaluated parameter criteria scores were then compared to each other. Where a difference in parameter criteria scores occurred - the most conservative value (i.e. the lowest value) was used in the final collation.

Finally in Stage 4, and based upon the final collated criteria scores, the values and ranges for $\mathrm{GS}(\mathrm{E}), \mathrm{GS}(\mathrm{S}), \mathrm{GS}(\mathrm{Ec}), \mathrm{GS}(\mathrm{A})$ and $\mathrm{GS}(\mathrm{T})$ were determined. ThEGS(T) and $\sum \mathrm{GS}(\overline{\mathrm{T}})$ values and ranges were then calculated. The overall results of the GAM evaluation were collated, tabularised, and graphically represented, as appropriate.

\subsection{Critical Evaluation of the GAM}

2.5.1. Potential Strengths and Benefits

Based upon and extending Phillips (2016), the strengths and benefits of the GAM are as follows: 
1. The provision of a quantitative-based assessment as to the level and nature of sustainability or unsustainability for: projects / developments; policies; strategies; legislative frameworks; or tools / indicators.

2. A consistent, transparent and rigorous approach for sustainability evaluation.

3. The ability to compare and contrast between: (i). similar projects, actions, or strategies; and/or (ii). different project or strategic options / alternatives.

4. A full justification of criteria scores for a chosen parameter, and in the analysis of the obtained values of GS(E), GS(S), GS(Ec), GS(A) and GS(T).

5. The ability to determine the nature of the co-evolutionary approach / strategy undertaken towards sustainability - whether ecocentric, anthropocentric, or holistic.

6. The GAM can be used as either: (i). a stand-alone tool; or (ii). as part of a larger assessment framework, such as a Strategic Environmental Assessment (SEA), in the assessment of sustainability

7. The ability of using further refinements in the determination of criteria scores e.g. using a weighted valuation approach; Analytical Hierarchy Process (AHP); D numbers; or an evidential reasoning approach (e.g. Ataei et al., 2008; Bogdanovic et al., 2012; Deng et al., 2014; Gilbuena et al., 2013; Huang et al., 2012; Li et al., 2014; Toro et al., 2013; Wang et al., 2006; Yang, 2001). 
8. The ability to evaluate the level and nature of sustainability or unsustainability over time - e.g. past-present-future; before-during-after; baseline-constructionoperation-post-operation; or annually, bi-annually, monthly etc.

9. Through the use of the fundamental geocybernetic paradigms and any resultant complex paradigms present, the assessor(s) can determine the nature of the proposed or actual pathway towards sustainability / sustainable development. For example: Optimization-dominant approach; or StandardizationStabilization (complex paradigm) strategy.

\subsubsection{Potential Disadvantages}

The potential disadvantages of the GAM, based upon and extending Phillips (2016), are as follows:

1. In order to properly apply the GAM, it does require a suitable level of knowledge and expertise in geocybernetic and sustainability science theory and practice. This is particularly the case for the evaluation of criteria scores for the chosen / determined parameters.

2. Without proper methodological approaches to ensure objectivity, the GAM can be subject to professional and/or commercial bias, and as a consequence, the criteria scores evaluated could be subjective in nature.

3. The GAM could be perceived as too complex and cumbersome by some in its approach in evaluating sustainability / unsustainability. 
4. Some may consider, or argue, that the GAM does not conform to the Brundtland Commission's definition of sustainable development, which have been widely implemented at all political and organisational levels.

5. The GAM is sensitive to the level of knowledge and abilities of the assessor(s) in the following respects: (i). its application; (ii). the correct determination of the scoping and criteria scores; and (iii). the analysis and discussion of the results.

\subsubsection{Potential GAM Shortcomings with EITI}

Within the context of the GAM's application to the EITI principles, there are some potential shortcomings in relation to three specific areas - knowledge and training; bias and subjectivity; and the GS value range. Therefore, it is worth discussing these potential shortcomings and how they could be addressed.

\subsubsection{Knowledge and Training}

The GAM does require an adequate level of knowledge and training in order to apply and operate it correctly. Specifically, the GAM uses a complex theoretical basis, as the means to evaluate and determine the potential effects of a policy, or strategic mechanism, upon the coupled environment-human system and relationship. The knowledge and training necessary would include a fundamental to good level of understanding of: earth system processes and interactions; the role and impact of the anthroposphere; earth system modelling and assessment; global environmental change; challenges and management of the earth system and environmental change; and sustainability. An Earth system perspective and its role in the era of global 
change. These topics are becoming part of the mainstream scientific academic curriculum. This is because it is being realised through research that human existence and activities are creating, and having, complex impacts and feedbacks at a variety of spatial-temporal scales. Therefore, the GAM is intended to provide a structured and fundamental methodological framework for evaluating the potential indicated sustainability of a policy or strategic mechanism, in respect to the coupled dynamic environment-human system and relationship.

Phillips (2016), in respect to EIA practice, stated that potential users or assessors would require a knowledge and training in areas such as the definition of an impact, the nature of impacts, the concept and evaluation of impact significance and the concept and evaluation of impact magnitude. Such concepts and practices should be taught at undergraduate and postgraduate level. Therefore reciprocally, it is certainly possible to acquire a fundamental to good level of knowledge and training in geocybernetic and environment-human systems theory in order to apply and operate the GAM. The knowledge required is in the authors' becoming an ever greater mainstream aspect, not only in academic research and training, but also for governments, businesses and NGOs, due to the accelerated global environmental change and the nature of its potential and actual consequences.

Another solution to the potential shortcoming of knowledge and training is the fact that the GAM is based on the RIAM, which is a semi-quantitative EIA methodology. Those with previous EIA-based training, knowledge and practice along with some fundamental knowledge and/or training of environment-human systems theory, should 
be able to apply and operate the GAM without an excessive degree of difficulty. There needs to be experts in the field, as part of the assessment team to conduct the GAM. This would mirror EIA practice, as carried out in academia and consultancies, where team members have a range of different specialist knowledge and training, which are brought together to conduct the assessment.

\subsubsection{Bias and Subjectivity}

In the GAM, there is certainly the possibility of bias and subjectivity occurring in the determination of criteria scores as described for Stages 2 and 3. Without proper safeguards to ensure objectivity, there is a potential risk that bias and subjectivity will occur. The outcome of this would be the skewing of the criteria scores to more favourable and unrealistic results, and this may consequently taint and undermine the remaining stages of the GAM evaluation. It is worth highlighting some steps which are available to mitigate these risks.

One potential approach is the use of an expert panel in the criteria scoring stages, and then the averaging of scores to produce a final overall criteria score. This should mitigate a potential bias in any members of a panel.

A more structured and robust potential approach is the evidential reasoning approach (Yang and Singh, 1994; Yang, 2001), which is used in RIAM-based evaluations (e.g. Wang et al., 2006; Li et al., 2014; Gilbuena et al., 2013). This approach adopts a belief structure in order to model qualitative assessments in multiple attribute decision making problems with uncertainties (Gholamalifard et al., 2016). This provides a 
systematic process to transform various types of information into a unified format, and results in both quantitative and qualitative information with uncertainties being handled in a consistent manner (Gholamalifard et al., 2016).

A further way to reduce bias and subjectivity is to have an appropriate level of knowledge and training with GAM application and operation. Comprehensive training on the theory, method and practice of the GAM, or indeed any similar methodological framework, is the cornerstone in ensuring that bias and subjectivity is significantly reduced to a minimum.

\subsubsection{The GS Value Range}

A potential concern which can be raised relates to the scoring approach adopted in the GAM. Specifically, in regards to the GS scores and value ranges. It may be a matter of concern as to why, for the sake of simplicity, a normalised scale of -1 to +1 was not adopted. The reason is simply because the GAM is based on the RIAM, and in a predominant sense, it inherited its scoring and value range approach. Therefore in the GAM, the GS scores can occur in a potential value range of $-486 \leq \mathrm{GS} \leq+486$.

The potential value range for GS should not be considered as a potential shortcoming, but rather a potential advantage. This is because the GS value range produces a significant range of sensitivity in the evaluation of the indicated level of sustainability or unsustainability. This is exemplified where GS scores are in a borderline region between GS levels, typically within a range of $\pm 1 \%$. The GS value range and potential scores, whilst some may consider them a bit cumbersome and unwieldy, 
does provide for the best opportunity to ensure accuracy and consistency in the results obtained.

\subsubsection{Potential Uses of the GAM}

The GAM is a potentially useful approach to evaluate all aspects of the EITI scheme, or for other policy drivers in the extractive sector or a country's minerals policy in the following regards:

1. The GAM is of value for those countries seeking EITI membership. It helps explore and frame potential sustainable development options for the attainment of transparency and accountability within policies, strategies, legislation, processes, and procedures.

2. The GAM can provide a mechanism for annual or other routine checks regarding the degree of EITI implementation and compliance in a country, with respect to sustainable development.

3. The GAM could be used as a means for assessing potential candidates' credentials for full membership to the EITI. Specifically, it is helpful in the evaluation of a country's commitment for the achievement of sustainable development.

4. The GAM could be used in order to determine the overall strategic direction of the EITI scheme, either at the organisational or the national level. The results of the GAM could be used to inform and influence any process of change in the 
direction of the scheme, as a mechanism for achieving a more conducive coevolutionary pathway towards sustainable development.

5. The GAM could be used a means to compare and contrast different countries' level of implementation and compliance in achieving sustainable development through the EITI scheme.

6. The GAM could be used to evaluate potential options at the organisational or national level specifically to improve or implement the EITI framework.

7. The GAM could be a potentially useful tool in evaluating any future restructuring or replacement(s) to the EITI scheme.

The list of potential uses of the GAM highlighted is not a definitive or exhaustive list. Furthermore, they are equally relevant to other policy or strategic drivers or aspects within the extractive sector or minerals policy, or to other policy drivers such as the 2008 Climate Change Act in the UK (see: Phillips, 2016). Furthermore, the GAM could be a useful tool to evaluate sustainability / sustainable development' credentials of different policy drivers in the extractive sector, such as companies who adopt the Global Reporting Initiative (GRI). Specifically, the GAM could be used to compare and contrast the GRI of various companies, with respect to their characteristics, strengths, and weaknesses, as a mechanism for contributing to and achieving a pathway towards sustainable development. Therefore, the GAM has a significant potential to be a valuable tool in the analysis of policy drivers in the extractive sector and in minerals policy. 


\section{Results and Analysis}

\subsection{Scoping}

The scoping of the EITI principles in regards to the five fundamental geocybernetic paradigms are provided in Table 4. Only Principle 3 did not indicate any evident fundamental paradigms and did not comply with the stated aspects of each of the fundamental paradigms. In the case of Principles 1 and 2, two paradigms were evaluated as non-existent. The reasons for this result will be explored in section 4.1. 
Table 4 GAM Scoping of the Principles of the EITI.

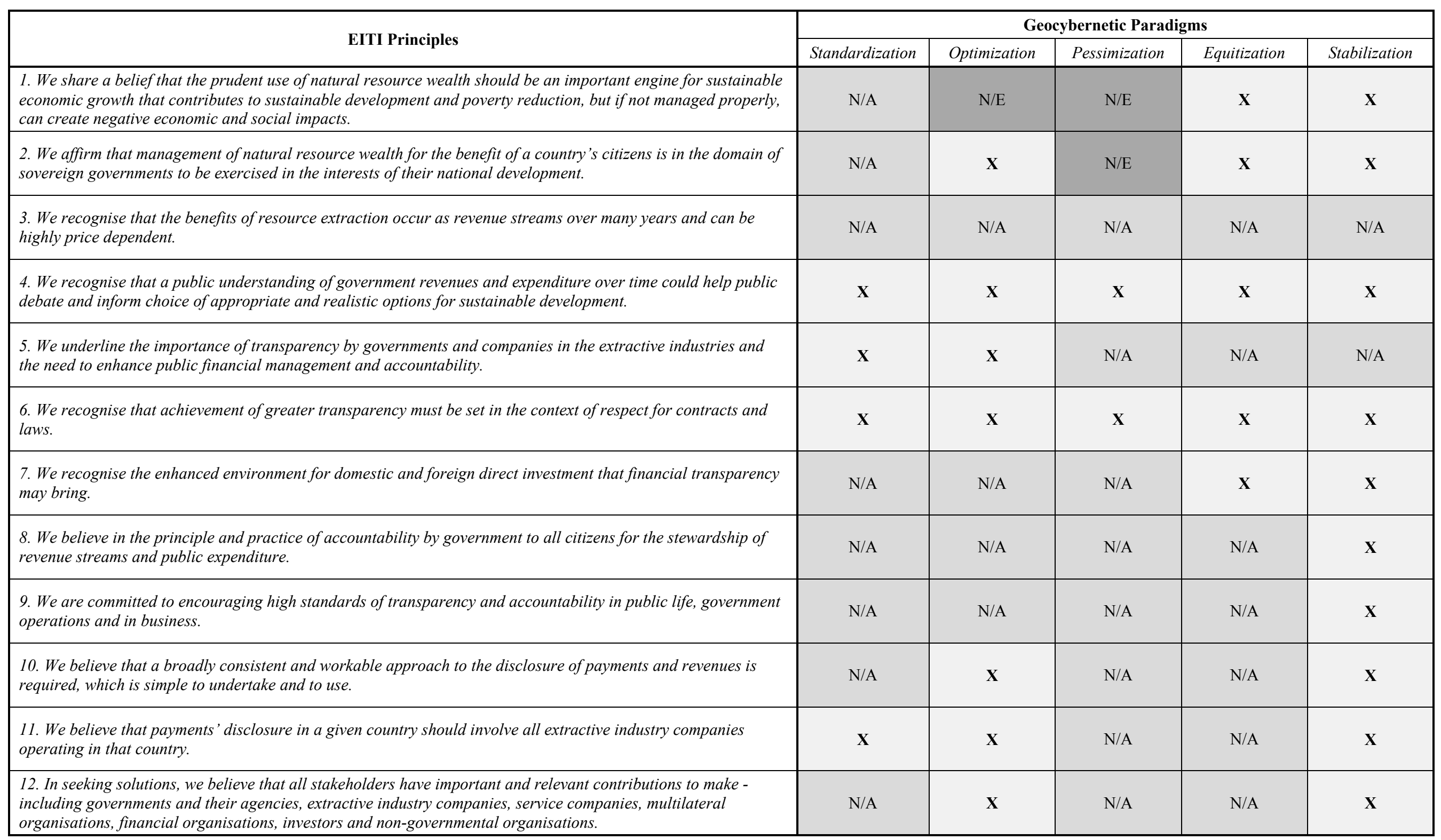

Key:

X - Paradigm present / evident; N/A - Paradigm non-applicable; N/E - Paradigm not evident / present 


\subsection{Geocybernetic Paradigms}

The results for the evaluation of Criteria A and B scores for the 12 principles are provided in the Appendix in Tables A2-A6. Based upon the criteria scores obtained, values for $\mathrm{GS}(\mathrm{E}), \mathrm{GS}(\mathrm{S}), \mathrm{GS}(\mathrm{Ec}) \mathrm{GS}(\mathrm{A})$ and $\mathrm{GS}(\mathrm{T})$ were determined, as shown in Tables 5-9. The results obtained shall now be examined in more depth.

\subsubsection{Standardization}

Four of the 12 principles were evaluated based on the scoping stage (Table 4). The evaluation and results provided in Tables 5 and A2 indicate that the principles were consistent with weak sustainability as the GS(T) values were within the range of +122 $\leq \mathrm{GS}(\mathrm{T}) \leq+242$ (re: Table $3 \mathrm{~b}$ ). The results further indicated that the omission of an environmental dimension within each of the principle's construction was a key potential factor. This is exemplified by the obtained values of GS(E). These ranged from 0 to +32 , indicating very weak unsustainability to very weak sustainability (environmental) (re: Table 3a). The obtained GS(S) and GS(Ec) totals, and the corresponding GS(A) totals ranged from +144 to +216 , indicating strong to very strong sustainability (anthropospheric) (re: Table 3a).

Consequently, there are indications that the EITI was conceived in line with the view that sustainable development is anthropocentric (social and economic) and not holistic (environmental-social-economic) in nature. This is supported by the obtained value for $\sum \mathrm{GS}(\overline{\mathrm{T}}) \rho_{0}$ (the overall Standardization paradigm GS(T) mean average) which was +206 , indicating weak sustainability (re: Table 5). This is because it is consistent with weak and strong sustainability theory concerning the relationship and management of 
natural and human capital (e.g. Costanza and Daly, 1992; Daly, 1994; Pearce and Turner, 1990). This indicates that the EITI's requirement for competence and determination from national governments, to ensure transparency and accountability occurs, is not as robust as it should be or portrayed. In addition, national governments must have robust mechanisms in place to evaluate and analyse progress within the EITI - successes and failures.

Table 5 GAM determination of the GS(A) values and the resultant GS(T) values and range for the determined EITI principles with respect to the Standardization paradigm.

\begin{tabular}{|c|c|c|c|c|c|c|}
\hline \multirow{2}{*}{ EITI Principles } & \multicolumn{6}{|c|}{ Geocybernetic Scores - Standardization } \\
\hline & GS(T) & $\begin{array}{c}\text { GS } \\
\text { Range }\end{array}$ & $G S(E)$ & $G S(A)$ & GS(S) & $\mathrm{GS}(\mathrm{Ec})$ \\
\hline $\begin{array}{l}\text { 4. We recognise that a public understanding of } \\
\text { government revenues and expenditure over time could } \\
\text { help public debate and inform choice of appropriate and } \\
\text { realistic options for sustainable development. }\end{array}$ & 212 & $+\mathbf{W}$ & 32 & 180 & 144 & 216 \\
\hline $\begin{array}{l}\text { 5. We underline the importance of transparency by } \\
\text { governments and companies in the extractive industries } \\
\text { and the need to enhance public financial management } \\
\text { and accountability. }\end{array}$ & 216 & $+\mathbf{W}$ & 0 & 216 & 216 & 216 \\
\hline $\begin{array}{l}\text { 6. We recognise that achievement of greater } \\
\text { transparency must be set in the context of respect for } \\
\text { contracts and laws. }\end{array}$ & 180 & $+\mathbf{W}$ & 0 & 180 & 216 & 144 \\
\hline $\begin{array}{l}\text { 11. We believe that payments' disclosure in a given } \\
\text { country should involve all extractive industry companies } \\
\text { operating in that country. }\end{array}$ & 216 & $+\mathbf{W}$ & 0 & 216 & 216 & 216 \\
\hline Overall Paradigm Average GS(T) $\left(\sum G S(\overline{\mathbf{T}}) \rho_{0}\right)$ & 206 & $+\mathbf{W}$ & & & & \\
\hline \multicolumn{7}{|c|}{ All values positive unless stated otherwise } \\
\hline
\end{tabular}




\subsubsection{Optimization}

Seven principles were identified and evaluated. The obtained GS(T) values ranged from +120 to +288 which indicated a range of very weak to strong sustainability occurring, as shown in Tables 6 and A3. The majority of the principles evaluated were consistent with weak sustainability $(+12 \underline{\mathrm{GS}}(\mathrm{T}) \leq+242 \quad-$ re: Table $3 \mathrm{~b})$. However, two principles (2 and 12) were evaluated as consistent with strong sustainability $(+243 \leq \mathrm{GS}(\mathrm{T}) \leq+364-$ re: Table $3 b)$. The GS(S) and GS(Ec) totals obtained were consistent with one another, and this reflected in the GS(A) totals. The GS(E) values ranged from -96 to +72 , indicating weak unsustainability to weak sustainability. This strongly impacted upon the level and nature of sustainability.

Within the context of Optimization, the results obtained strongly indicate that the environment is not properly accounted for. Whilst Principles 2 and 12 have GS(T) values consistent with strong sustainability, the precise nature of that sustainability could still be considered as anthropocentric, given the disparity between the respective obtained GS(E) and GS(A) values. The majority of the principles, as indicated in Table 6, do not strongly advocate environmental transparency or accountability in way of ensuring the development of an optimal pathway towards sustainable development. Therefore, this may result in some form of environmental collapse at the local level, as indicated in Figure 1. It is only when the environment is properly assessed and accounted for within any sustainable strategy and/or approach, that a meaningful and optimal pathway, towards a co-evolutionary relationship between the environment and humanity, can be achieved. 
Table 6 GAM determination of the GS(A) values and the resultant GS(T) values and range for the determined EITI principles with respect to the Optimization paradigm.

\begin{tabular}{|c|c|c|c|c|c|c|}
\hline \multirow{2}{*}{ EITI Principles } & \multicolumn{6}{|c|}{ Geocybernetic Scores - Optimization } \\
\hline & GS(T) & $\begin{array}{c}\text { GS } \\
\text { Range }\end{array}$ & $G S(E)$ & $G S(A)$ & $\mathrm{GS}(\mathrm{S})$ & $\mathrm{GS}(\mathrm{Ec})$ \\
\hline $\begin{array}{l}\text { 2. We affirm that management of natural resource } \\
\text { wealth for the benefit of a country's citizens is in the } \\
\text { domain of sovereign governments to be exercised in the } \\
\text { interests of their national development. }\end{array}$ & 264 & $+\mathbf{S}$ & 48 & 216 & 216 & 216 \\
\hline $\begin{array}{l}\text { 4. We recognise that a public understanding of } \\
\text { government revenues and expenditure over time could } \\
\text { help public debate and inform choice of appropriate and } \\
\text { realistic options for sustainable development. }\end{array}$ & 240 & $+\mathbf{W}$ & 24 & 216 & 216 & 216 \\
\hline $\begin{array}{l}\text { 5. We underline the importance of transparency by } \\
\text { governments and companies in the extractive industries } \\
\text { and the need to enhance public financial management } \\
\text { and accountability. }\end{array}$ & 216 & $+\mathbf{W}$ & 0 & 216 & 216 & 216 \\
\hline $\begin{array}{l}\text { 6. We recognise that achievement of greater } \\
\text { transparency must be set in the context of respect for } \\
\text { contracts and laws. }\end{array}$ & 216 & $+\mathbf{W}$ & 0 & 216 & 216 & 216 \\
\hline $\begin{array}{l}\text { 10. We believe that a broadly consistent and workable } \\
\text { approach to the disclosure of payments and revenues is } \\
\text { required, which is simple to undertake and to use. }\end{array}$ & 168 & $+\mathbf{W}$ & -48 & 216 & 216 & 216 \\
\hline $\begin{array}{l}\text { 11. We believe that payments' disclosure in a given } \\
\text { country should involve all extractive industry companies } \\
\text { operating in that country. }\end{array}$ & 120 & $+\mathbf{W}$ & -96 & 216 & 216 & 216 \\
\hline $\begin{array}{l}\text { 12. In seeking solutions, we believe that all stakeholders } \\
\text { have important and relevant contributions to make - } \\
\text { including governments and their agencies, extractive } \\
\text { industry companies, service companies, multilateral } \\
\text { organisations, financial organisations, investors and } \\
\text { non-governmental organisations. }\end{array}$ & 288 & $+\mathbf{S}$ & 72 & 216 & 216 & 216 \\
\hline Overall Paradigm Average GS(T) $\left(\sum \mathbf{G S}(\overline{\mathbf{T}}) \rho_{1}\right)$ & 216 & $+\mathbf{W}$ & & & & \\
\hline
\end{tabular}




\subsubsection{Pessimization}

Based on Table 4, only two principles were considered as displaying traits consistent with this paradigm - Principles 4 and 6 . The former was consistent with very weak sustainability (Tables 7 and A4). This result was based on a GS(T) value of +24 derived from a GS(E) value of -72 and a GS(A) value of +96 . There are significant weaknesses in both environmental and anthropospheric components.

Principle 6 had a GS(T) value of +240 , indicative of weak sustainability (Tables 7 and A4). This was based on a GS(E) value of +24 and a GS(A) value of +216 . The obtained GS(T) was just below the minimum threshold for strong sustainability $(+243$ $\leq \mathrm{GS}(\mathrm{T}) \leq+364$ - re: Table $3 \mathrm{~b}$ ), and as a result could be considered as borderline weak-strong sustainability. The results for Principle 6 were compounded by the evident continuing weakness of the environmental dimension. Whilst the GS(E) value was positive, there was an indication of significant weakness within the principle, due to the very weak sustainability associated with the environmental dimension (re: Tables 7 and A4). This result stems from the lack of clarity concerning the nature and level of transparency required in contracts and laws governing environmental issues. The GS(S) and GS(Ec) values obtained, as well as the consequential GS(A) value, were however all indicative of the potential socio-economic benefits derived from extractive industries. The GS(T) values for Principle 4 and 6 , resulted in $\operatorname{a} \sum \mathrm{GS}(\overline{\mathrm{T}}) \rho_{2}$ value of +132 (the overall mean average Pessimization paradigm GS(T) value), indicative of weak sustainability (Table 7). This obtained $\sum \mathrm{GS}(\overline{\mathrm{T}}) \rho_{1}$ value was just within the designated value range for weak sustainability, as indicated in Table $3 b$. 
This may suggest borderline weak to very weak sustainability with respect to the Pessimization paradigm.

The overall consequence of the results of Principles 4 and 6, is that the EITI does not encourage or adopt an approach consistent with the precautionary principle. This is a potentially disconcerting outcome with respect to the strategic implementation and management of sustainable development.

Table 7 GAM determination of the GS(A) values and the resultant GS(T) values and range for the determined EITI principles with respect to the Pessimization paradigm.

\begin{tabular}{|l|c|c|c|c|c|c|}
\hline \multicolumn{1}{|c|}{ EITI Principles } & \multicolumn{5}{|c|}{ Geocybernetic Scores - Pessimization } \\
\cline { 2 - 7 } & GS(T) & $\begin{array}{c}\text { GS } \\
\text { Range }\end{array}$ & $G S(E)$ & $G S(A)$ & GS(S) & GS(Ec) \\
\hline $\begin{array}{l}\text { 4. We recognise that a public understanding of } \\
\text { government revenues and expenditure over time could } \\
\text { help public debate and inform choice of appropriate and } \\
\text { realistic options for sustainable development. }\end{array}$ & $\mathbf{2 4}$ & $+\mathbf{V W}$ & -72 & 96 & 96 & 96 \\
$\begin{array}{l}\text { 6. We recognise that achievement of greater } \\
\text { transparency must be set in the context of respect for } \\
\text { contracts and laws. }\end{array}$ & $\mathbf{2 4 0}$ & $+\mathbf{W}$ & 24 & 216 & 216 & 216 \\
\hline All values positive unless stated otherwise & & & & & \\
\hline
\end{tabular}




\subsubsection{Equitization}

Based on the scoping stage outlined in Table 3, five of the 12 principles were deemed as consistent with this paradigm. The obtained GS(T) values for the principles evaluated ranged from +72 to +149 , which indicates a range of very weak to weak sustainability, as shown in Table 9. The obtif $\overline{\mathrm{T}}) \rho_{3}$ value was +119 , indicating very weak sustainability (re: Table $3 b$ ). Whilst the obtained values of $\mathrm{GS}(\mathrm{S})$ and $\mathrm{GS}(\mathrm{Ec})$, and the corresponding GS(A) values, were similar - this was not the case for the GS(E) values.

The values of $\mathrm{GS}(\mathrm{E})$ ranged fro $2 \mathrm{~m}$ to -144 indicating weak to strong unsustainability (Tables 8 and A5). The inferred consequence of this is that the equity of resources and services within the EITI is primarily focused upon present anthropocentric needs and concerns. This therefore potentially compromises the available environmental resources and services for future generations, at all spatialtemporal scales. 
Table 8 GAM determination of the GS(A) values and the resultant GS(T) values and range for the determined EITI principles with respect to the Equitization paradigm.

\begin{tabular}{|c|c|c|c|c|c|c|}
\hline \multirow{2}{*}{ EITI Principles } & \multicolumn{6}{|c|}{ Geocybernetic Scores - Equitization } \\
\hline & GS(T) & $\begin{array}{c}\text { GS } \\
\text { Range }\end{array}$ & $G S(E)$ & $G S(A)$ & GS(S) & $\mathrm{GS}(\mathrm{Ec})$ \\
\hline $\begin{array}{l}\text { 1. We share a belief that the prudent use of natural } \\
\text { resource wealth should be an important engine for } \\
\text { sustainable economic growth that contributes to } \\
\text { sustainable development and poverty reduction, but if } \\
\text { not managed properly, can create negative economic } \\
\text { and social impacts. }\end{array}$ & 120 & $+\mathbf{V W}$ & -96 & 216 & 216 & 216 \\
\hline $\begin{array}{l}\text { 2. We affirm that management of natural resource } \\
\text { wealth for the benefit of a country's citizens is in the } \\
\text { domain of sovereign governments to be exercised in the } \\
\text { interests of their national development. }\end{array}$ & 72 & $+\mathbf{V W}$ & -144 & 216 & 216 & 216 \\
\hline $\begin{array}{l}\text { 4. We recognise that a public understanding of } \\
\text { government revenues and expenditure over time could } \\
\text { help public debate and inform choice of appropriate and } \\
\text { realistic options for sustainable development. }\end{array}$ & 144 & $+\mathbf{W}$ & -72 & 216 & 216 & 216 \\
\hline $\begin{array}{l}\text { 6. We recognise that achievement of greater } \\
\text { transparency must be set in the context of respect for } \\
\text { contracts and laws. }\end{array}$ & 108 & $+V W$ & -72 & 180 & 216 & 144 \\
\hline $\begin{array}{l}\text { 7. We recognise the enhanced environment for domestic } \\
\text { and foreign direct investment that financial } \\
\text { transparency may bring. }\end{array}$ & 149 & $+\mathbf{W}$ & -81 & 230 & 216 & 243 \\
\hline Overall Paradigm Average GS(T) $\left(\sum G S(\bar{T}) \rho_{3}\right)$ & 119 & $+\mathbf{V W}$ & & & & \\
\hline & ot & herwi & & & & \\
\hline
\end{tabular}

\subsubsection{Stabilization}

As shown in Table 4, the scoping stage indicated that ten of the 12 principles were considered as consistent with this paradigm. This provides a strong indication of the intended fundamental pathway towards sustainable development. The obtained GS(T) values show significant variations in the level and nature of sustainability (Table 9). The range of obtained $\mathrm{GS}(\mathrm{T})$ values was the most variable, going from 0 to +432 , indicating very weak unsustainability to very strong sustainability (re: Table $3 b$ ). This suggests a significant variation in the potential outcomes regarding the management of 
the environment-human system towards co-evolution. The significant variations of obtained GS(T) values, as indicated in Tables 9 and A6, were predominantly related to the fluctuations in the values obtained for GS(E).

The GS(E) values ranged from 216 to +216 , indicating strong unsustainability to very strong sustainability occurring (re: Table $3 a$ ). This was contrary to the GS(A) values, where the majority of values were determined as +216 , indicating very strong sustainability (re: Table 3a). The only exception to this was Principle 7, which had a GS(A) value of +80 , based on a $\mathrm{GS}(\mathrm{S})$ value of +16 and a $\mathrm{GS}(\mathrm{Ec})$ value of +144 . This indicates a more dominant economic aspect to the co-evolutionary management of the environment-human system. The other principles show a dominant anthropocentric approach reflected in their respective values for GS(S), GS(Ec) and GS(A) compared to their GS(E) values. These GS(E) values were predominantly negative or zero, as indicated in Tables 10 and A5.

Principle 8 had an obtained GS(T) value of +168 , indicating weak sustainability. This was primarily due to a $\mathrm{GS}(\mathrm{E})$ value of -48 compared to a GS(A) value of +216 . This relates to the principle's goal of improving accountability in the stewardship of financial and economic benefits derived from resource extraction. The EITI fails however to promote or entrench environmental stewardship of resources. This is partly because of Principle 1's anthropocentric perspective of sustainable development. 
Principles 9 and 12, on the other hand, had GS(E) values of +72 and +216 respectively. In conjunction with their GS(A) values, this suggests how Principles 9 and 12 had obtained GS(T) values of +288 (strong sustainability) and +432 (very strong sustainability) respectively. This indicates that good to strong co-evolutionary management can be implemented.

Overall, the majority of the principles evaluated were consistent with either very weak unsustainability or very weak sustainability. Only Principles 9 and 12 had values consistent with strong and very strong sustainability. The implication of this, within the context of the paradigm, is that management towards co-evolution (sustainable development) is fundamentally very weak in nature. This is because the management strategy is predominantly anthropocentric (socio-economic) rather than holistic (environmental-social-economic), as is required to achieve the co-evolution of the environment-human system. 
Table 9 GAM determination of the GS(A) values and the resultant GS(T) values and range for the determined EITI principles with respect to the Stabilization paradigm.

\begin{tabular}{|c|c|c|c|c|c|c|}
\hline \multirow{2}{*}{ EITI Principles } & \multicolumn{6}{|c|}{ Geocybernetic Scores - Stabilization } \\
\hline & GS(T) & $\begin{array}{c}\text { GS } \\
\text { Range }\end{array}$ & $G S(E)$ & $G S(A)$ & $\mathrm{GS}(\mathrm{S})$ & $\mathrm{GS}(\mathrm{Ec})$ \\
\hline $\begin{array}{l}\text { 1. We share a belief that the prudent use of natural resource wealth should be an important engine for sustainable } \\
\text { economic growth that contributes to sustainable development and poverty reduction, but if not managed properly, can } \\
\text { create negative economic and social impacts. }\end{array}$ & $\mathbf{0}$ & $-\mathbf{V W}$ & -216 & 216 & 216 & 216 \\
\hline $\begin{array}{l}\text { 2. We affirm that management of natural resource wealth for the benefit of a country's citizens is in the domain of } \\
\text { sovereign governments to be exercised in the interests of their national development. }\end{array}$ & $\mathbf{0}$ & $-\mathbf{V W}$ & -216 & 216 & 216 & 216 \\
\hline $\begin{array}{l}\text { 4. We recognise that a public understanding of government revenues and expenditure over time could help public } \\
\text { debate and inform choice of appropriate and realistic options for sustainable development. }\end{array}$ & 72 & $+\mathbf{V W}$ & -144 & 216 & 216 & 216 \\
\hline 6. We recognise that achievement of greater transparency must be set in the context of respect for contracts and laws. & $\mathbf{0}$ & $-\mathbf{V W}$ & -216 & 216 & 216 & 216 \\
\hline $\begin{array}{l}\text { 7. We recognise the enhanced environment for domestic and foreign direct investment that financial transparency may } \\
\text { bring. }\end{array}$ & 80 & $+\mathbf{V W}$ & 0 & 80 & 16 & 144 \\
\hline $\begin{array}{l}\text { 8. We believe in the principle and practice of accountability by government to all citizens for the stewardship of } \\
\text { revenue streams and public expenditure. }\end{array}$ & 168 & $+\mathbf{W}$ & -48 & 216 & 216 & 216 \\
\hline $\begin{array}{l}\text { 9. We are committed to encouraging high standards of transparency and accountability in public life, government } \\
\text { operations and in business. }\end{array}$ & 288 & $+\mathbf{S}$ & 72 & 216 & 216 & 216 \\
\hline $\begin{array}{l}\text { 10. We believe that a broadly consistent and workable approach to the disclosure of payments and revenues is } \\
\text { required, which is simple to undertake and to use. }\end{array}$ & 72 & $+\mathbf{V W}$ & -144 & 216 & 216 & 216 \\
\hline $\begin{array}{l}\text { 11. We believe that payments' disclosure in a given country should involve all extractive industry companies operating } \\
\text { in that country. }\end{array}$ & 72 & $+\mathbf{V W}$ & -144 & 216 & 216 & 216 \\
\hline $\begin{array}{l}\text { 12. In seeking solutions, we believe that all stakeholders have important and relevant contributions to make- } \\
\text { including governments and their agencies, extractive industry companies, service companies, multilateral } \\
\text { organisations, financial organisations, investors and non-governmental organisations. }\end{array}$ & 432 & $+\mathbf{V S}$ & 216 & 216 & 216 & 216 \\
\hline Overall Paradigm Average GS(T) $\left(\sum \mathrm{GS}(\overline{\mathbf{T}}) \rho_{4}\right)$ & 118 & $+\mathbf{V W}$ & & & & \\
\hline
\end{tabular}




\subsection{Complex Paradigm}

As stated earlier, this paradigm is where two or more fundamental geocybernetic paradigms are present. As indicated during the scoping stage (Table 4) and Table 10, nine of the 12 principles exhibited traits of a complex paradigm. The obtained GS(T) values for those principles exhibiting a complex paradigm ranged from +60 to +360 , indicating very weak to strong sustainability (re: Table $3 b$ ). Based on the mean average paradigm GS(T) values obtained, the $\sum \mathrm{GS}(\overline{\mathrm{T}}) \rho$ value was +158 , as shown in Table 11. This falls within the GS(T) value range of weak sustainability (re: Table 3b). This further supports the findings regarding a lack of an environmental dimension and approach towards the development and management of a coevolutionary relationship. It also means that the overall nature of the "sustainable development pathway" established by the EITI is anthropocentric in nature. 
Table 10 Final determination of GS(T) values and ranges for the five fundamental geocybernetic paradigms, and the determination of the GS(T) values and ranges for complex paradigms.

\begin{tabular}{|c|c|c|c|c|c|c|c|c|c|c|c|c|}
\hline \multirow{3}{*}{ EITI Principles } & \multicolumn{12}{|c|}{ Geocybernetic Paradigms } \\
\hline & \multicolumn{2}{|c|}{ Standardization } & \multicolumn{2}{|c|}{ Optimization } & \multicolumn{2}{|c|}{ Pessimization } & \multicolumn{2}{|c|}{ Equitization } & \multicolumn{2}{|c|}{ Stabilization } & \multicolumn{2}{|c|}{ Complex } \\
\hline & GS(T) & $\begin{array}{l}\text { GS(T) } \\
\text { Range }\end{array}$ & $\mathrm{GS}(\mathrm{T})$ & $\begin{array}{l}\text { GS(T) } \\
\text { Range }\end{array}$ & $\mathrm{GS}(\mathrm{T})$ & $\begin{array}{l}\text { GS(T) } \\
\text { Range }\end{array}$ & $\mathrm{GS}(\mathrm{T})$ & $\begin{array}{l}\text { GS(T) } \\
\text { Range }\end{array}$ & GS(T) & $\begin{array}{l}\text { GS(T) } \\
\text { Range }\end{array}$ & $\sum G S(\bar{T}) \rho$ & $\begin{array}{l}\text { GS(T) } \\
\text { Range }\end{array}$ \\
\hline $\begin{array}{l}\text { 1. We share a belief that the prudent use of natural resource wealth should be an important engine for } \\
\text { sustainable economic growth that contributes to sustainable development and poverty reduction, but if not } \\
\text { managed properly, can create negative economic and social impacts. }\end{array}$ & & & & & & & 120 & $+\mathrm{VW}$ & 0 & $-\mathrm{VW}$ & 60 & $+\mathbf{V W}$ \\
\hline $\begin{array}{l}\text { 2. We affirm that management of natural resource wealth for the benefit of a country's citizens is in the } \\
\text { domain of sovereign governments to be exercised in the interests of their national development. } \\
\text { 3. We recognise that the benefits of resource extraction occur as revenue streams over many years and can } \\
\text { be highly price dependent. }\end{array}$ & & & 264 & & & & 72 & $+\mathrm{VW}$ & 0 & $-\mathrm{VW}$ & 112 & $+\mathrm{VW}$ \\
\hline $\begin{array}{l}\text { 4. We recognise that a public understanding of government revenues and expenditure over time could help } \\
\text { public debate and inform choice of appropriate and realistic options for sustainable development. }\end{array}$ & 212 & $+\mathrm{W}$ & 240 & $+\mathrm{W}$ & 24 & $+\mathrm{VW}$ & 144 & $+\mathrm{W}$ & 72 & $+\mathrm{VW}$ & 138 & $+\mathbf{W}$ \\
\hline $\begin{array}{l}\text { 5. We underline the importance of transparency by governments and companies in the extractive industries } \\
\text { and the need to enhance public financial management and accountability. }\end{array}$ & 216 & $+\mathrm{W}$ & 216 & $+\mathrm{W}$ & & & & & & & 216 & $+\mathbf{W}$ \\
\hline $\begin{array}{l}\text { 6. We recognise that achievement of greater transparency must be set in the context of respect for contracts } \\
\text { and laws. }\end{array}$ & 180 & $+\mathrm{W}$ & 216 & $+\mathrm{W}$ & 240 & $+\mathrm{W}$ & 108 & $+\mathrm{VW}$ & 0 & $-\mathrm{VW}$ & 149 & $+W$ \\
\hline $\begin{array}{l}\text { 7. We recognise the enhanced environment for domestic and foreign direct investment that financial } \\
\text { transparency may bring. }\end{array}$ & & & & & & & 149 & $+\mathrm{W}$ & 80 & $+\mathrm{VW}$ & 114 & $+\mathbf{V W}$ \\
\hline $\begin{array}{l}\text { 8. We believe in the principle and practice of accountability by government to all citizens for the stewardship } \\
\text { of revenue streams and public expenditure. }\end{array}$ & & & & & & & & & 168 & $+\mathrm{W}$ & & \\
\hline $\begin{array}{l}\text { 9. We are committed to encouraging high standards of transparency and accountability in public life, } \\
\text { government operations and in business. }\end{array}$ & & & & & & & & & 288 & $+\mathrm{S}$ & & \\
\hline $\begin{array}{l}\text { 10. We believe that a broadly consistent and workable approach to the disclosure of payments and revenues } \\
\text { is required, which is simple to undertake and to use. }\end{array}$ & & & 168 & $+\mathrm{W}$ & & & & & 72 & $+\mathrm{VW}$ & 120 & $+W$ \\
\hline $\begin{array}{l}\text { 11. We believe that payments' disclosure in a given country should involve all extractive industry companies } \\
\text { operating in that country. }\end{array}$ & 216 & $+\mathrm{W}$ & 120 & $+\mathrm{W}$ & & & & & 72 & $+\mathrm{VW}$ & 136 & $+\mathbf{W}$ \\
\hline $\begin{array}{l}\text { 12. In seeking solutions, we believe that all stakeholders have important and relevant contributions to make - } \\
\text { including governments and their agencies, extractive industry companies, service companies, multilateral } \\
\text { organisations, financial organisations, investors and non-governmental organisations. }\end{array}$ & & & 288 & $+\mathrm{S}$ & & & & & 432 & $+\mathrm{VS}$ & 360 & $+\mathbf{S}$ \\
\hline Overall Paradigm Average GS(T) $\left(\sum G S(\bar{T}) \rho_{x}\right)$ & 206 & $+\mathbf{W}$ & 216 & $+\mathbf{W}$ & 132 & $+\mathbf{W}$ & 119 & $+\mathbf{V W}$ & 118 & $+\mathbf{V W}$ & & \\
\hline
\end{tabular}


Table 11 The final average paradigm GS(T) value and range for each geocybernetic paradigm.

\begin{tabular}{c|c|c}
\hline \hline Geocybernetic Paradigm & $\begin{array}{c}\text { Average } \\
\sum \mathbf{G S}(\overline{\mathbf{T}}) \boldsymbol{\rho}_{\boldsymbol{x}}\end{array}$ & $\mathbf{G S ( T ) \text { Range }}$ \\
\hline \hline Standardization & 206 & $+\mathrm{W}$ \\
Optimization & 216 & $+\mathrm{W}$ \\
Pessimization & 132 & $+\mathrm{W}$ \\
Equitization & 119 & $+\mathrm{VW}$ \\
Stabilization & 118 & $+\mathrm{VW}$ \\
\hline Complex $\left(\sum \mathbf{G S}(\overline{\mathbf{T}}) \boldsymbol{\rho}\right)$ & $\mathbf{1 5 8}$ & $+\mathrm{W}$ \\
\hline
\end{tabular}

\subsection{Analysis of Results}

Table 12 and Figure 3 show the nature and type of GS(T) ranges for each paradigm obtained, with respect to the assessed principles (excluding Principle 3). The most common result was weak sustainability (18), whereby the GS(T) value was within a range of $+122 \leq \mathrm{GS}(\mathrm{T}) \leq+242$ ( re: Table $3 \mathrm{~b})$. The second most common was weak sustainability (11), whereby the GS(T) values were within the range of $+\underline{k} \mathrm{GS}(\mathrm{T}) \leq$ +121 . With respect to the nature of complex paradigms present, there was no dominant complex paradigm type, as indicated by Table 13a. 
Table 12 Determination of the frequency of GS(T) ranges determined for the EITI principles with respect to the geocybernetic paradigms.

\begin{tabular}{l|cccccccc}
\multirow{2}{*}{$\begin{array}{c}\text { Geocybernetic } \\
\text { Paradigm }\end{array}$} & \multicolumn{7}{|c}{ GS(T) Ranges } \\
\cline { 2 - 9 } & $-\mathrm{VS}$ & $-\mathrm{S}$ & $-\mathrm{W}$ & $-\mathrm{VW}$ & $+\mathrm{VW}$ & $+\mathrm{W}$ & $+\mathrm{S}$ & $+\mathrm{VS}$ \\
\hline Standardization & 0 & 0 & 0 & 0 & 0 & 4 & 0 & 0 \\
Optimization & 0 & 0 & 0 & 0 & 0 & 5 & 2 & 0 \\
Pessimization & 0 & 0 & 0 & 0 & 1 & 1 & 0 & 0 \\
Equitization & 0 & 0 & 0 & 0 & 3 & 2 & 0 & 0 \\
Stabilization & 0 & 0 & 0 & 3 & 4 & 1 & 1 & 1 \\
Complex & 0 & 0 & 0 & 0 & 3 & 5 & 1 & 0 \\
\hline Total & $\mathbf{0}$ & $\mathbf{0}$ & $\mathbf{0}$ & $\mathbf{3}$ & $\mathbf{1 1}$ & $\mathbf{1 8}$ & 4 & $\mathbf{1}$ \\
\hline
\end{tabular}


a)

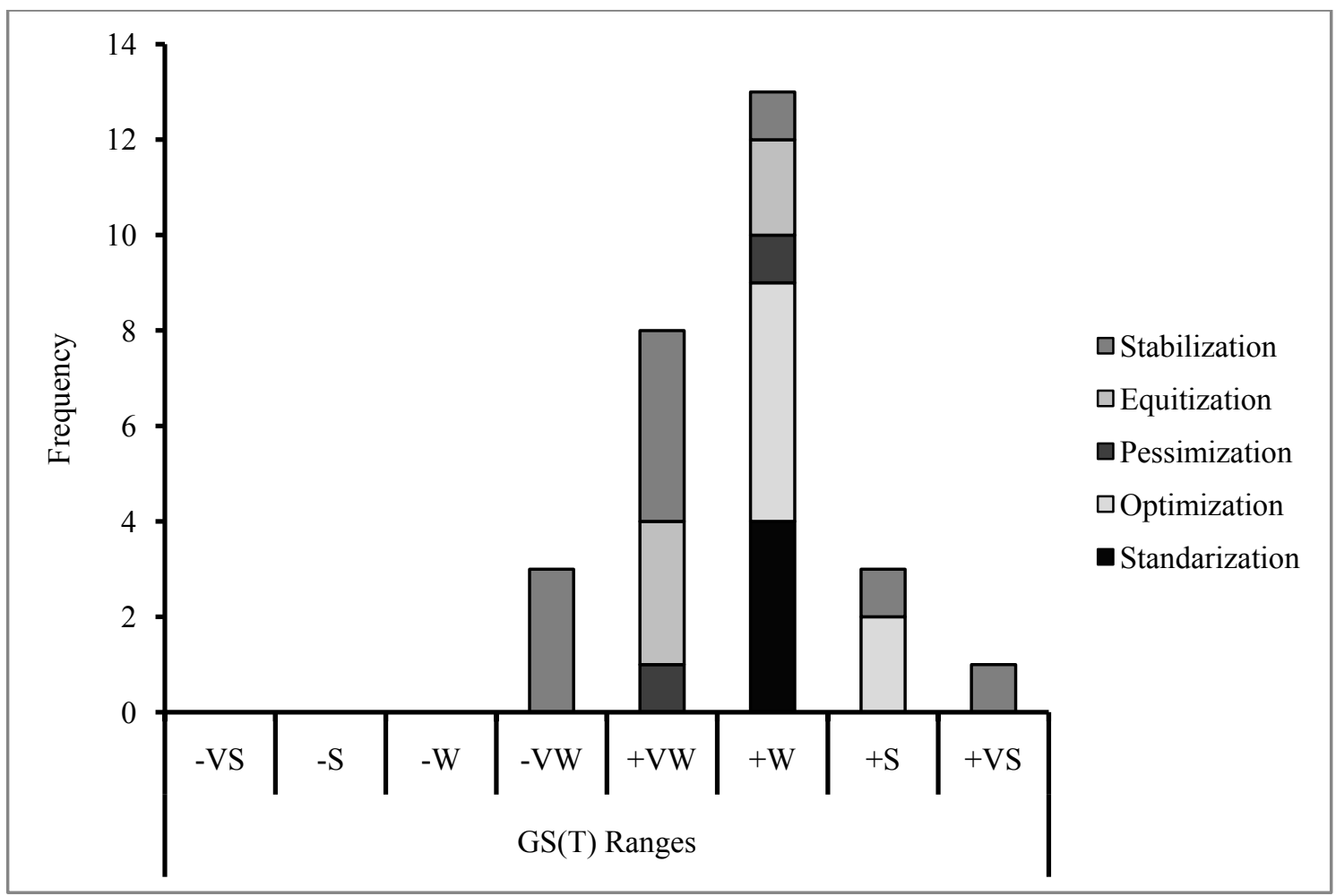

b)

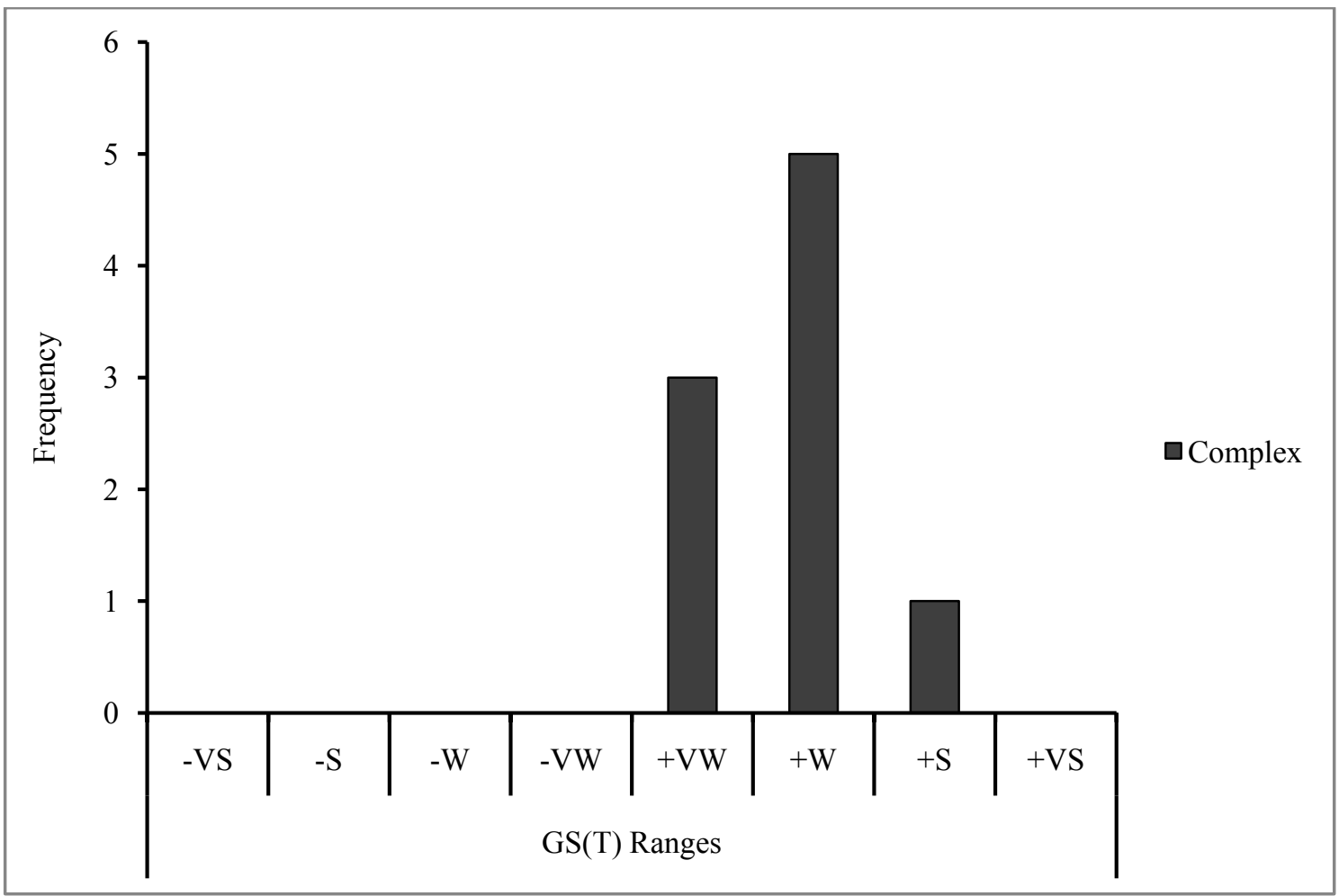

Figure 3 Graphical representation of the frequency of the GS(T) ranges determined for a) fundamental and b) complex geocybernetic paradigms. 
Table 13 The number of geocybernetic paradigms present. a) the number of nature of each complex paradigm set type; and b) number of appearance for each fundamental paradigm on an individual basis and within each determined complex paradigm set.

a)

\begin{tabular}{c|c} 
Paradigm / Complex Set Type & No. of Determined Set Type \\
\hline Eq-Sb & 2 \\
Op-Eq-Sb & 1 \\
St-Op-P-Eq-Sb & 2 \\
St-Op & 1 \\
Op-Sb & 2 \\
St-Op-Sb & 1 \\
Key: & \\
St - Standardization; Op - Optimization; P - Pessimization; \\
Eq - Equitization; Sb - Stabilization
\end{tabular}

b)

\begin{tabular}{c|c|c} 
Paradigm / Category & $\begin{array}{c}\text { Overall No. of Individual } \\
\text { Appearances }\end{array}$ & $\begin{array}{c}\text { No. of Individual Appearances } \\
\text { in a Determined Complex Set }\end{array}$ \\
\hline Standardization & 4 & 4 \\
Optimization & 7 & 7 \\
Pessimization & 2 & 2 \\
Equitization & 5 & 5 \\
Stabilization & 10 & 8 \\
N/E & 3 & - \\
N/A & 29 & -
\end{tabular}

Key:

N/E - Non-existent ; N/A - Non-applicable

Table $13 \mathrm{~b}$ indicates that the most dominant fundamental paradigm within a complex paradigm set was Stabilization, closely followed by Optimization. Stabilization was also the most prolific fundamental paradigm in respect to the number of individual appearances in the principles, as indicated by Table 13b. This was due to it being the sole paradigm evaluated for Principles 8 and 9. The results provided in Tables 5-10 (and Tables A2-A6) indicate that the EITI principles are an attempt to foster good management (Stabilization) through the use of an optimal pathway (Optimization) 
towards sustainable development. However, the EITI fails to accomplish this generally speaking because of the nature of sustainability being achieved, which is, more often than not, weak to very weak. As detailed earlier, this is because of the omission of a significant environmental dimension, as a means to foster sustainable development through effective transparency and accountability. This was demonstrated by the non-existence of key geocybernetic paradigms in respect to Principles 1 and 2. The non-existence of a paradigm is of profound significance as it is a less desirable outcome than the non-applicability of a paradigm. Principles 1 and 2 are crucial to the EITI in stating the initiative's overall intention and direction yet Optimization and/or Pessimization are not present, which is a noteworthy omission. With respect to Optimization, Principle 1 fails to clearly establish the best pathway for achieving the co-evolution of the environment-human system (sustainable development).

The approach taken by the EITI towards sustainable development is, as stated before, anthropocentric in nature, and exclusively based upon the definitions and notions stated within the Brundtland Commission's report (WCED, 1987). There is no clear statement or commitment within the EITI as to the need to maintain environmental resources or services for the present or future generations through transparency and/or accountability. Therefore, the risk of the overexploitation of natural resource wealth, severely compromising environmental system, remains. This is not conducive towards an optimal pathway towards sustainable development. 
With respect to Pessimization, neither Principles 1 nor 2 exhibited the notion of the precautionary principle, which should ensure the minimum amount of environmental impact for the maximum amount of socio-economic benefit. Whilst both principles do stress the importance of using natural resource wealth for the social and economic development of a country - the minimisation of environmental impacts is neither stated nor implied. It is worthy of note that the environment, as a whole, is not mentioned either in Principle 1 or 2.

This explains why the non-existence of the Optimization and Pessimization paradigms occurred during the scoping stage (re: Table 3). The reduction and mitigation of environmental impacts, as part of the statements concerning the prudent use (Principle 1) and management (Principle 2) of natural resource wealth, is not stated. Furthermore, the non-implementation of the Pessimization paradigm may lead to the status quo scenario just described for Optimization.

\section{Discussion}

\subsection{Overview}

From the results and analysis conducted, it appears that the EITI is fundamentally inadequate. The environmental elements are not accounted for, due to the adoption of a one dimensional Brundtland approach to sustainable development. Only by further analysis of the results in regards to the core EITI principles of 1 and 2, through a geocybernetic perspective, can more deterministic conclusions be drawn. 


\subsection{EITI Principles 1 and 2 - A Geocybernetic Perspective}

\subsubsection{Principle 1}

This principle outlines the fundamental ethos behind the EITI. As a consequence, it is necessary to examine this principle in more detail. Principle 1 states that: "We share a belief that the prudent use of natural resource wealth should be an important engine for sustainable economic growth that contributes to sustainable development and poverty reduction, but if not managed properly, can create negative economic and social impacts" (EITI, 2015a, p9). The results indicate that the principle exhibits an Equitization-Stabilization complex paradigm, which was evaluated as very weak in nature, as shown in Table 10.

The principle, with respect to the Equitization paradigm, was evaluated as consistent with very weak sustainability based on an obtained GS(T) score of +120 . As Table 7 indicates, the principle scored negatively in respect to the GS(E) score 96 ), which had a significant impact upon the final GS(T) score. Considering the fact that Equitization is based upon the notion of intra- and inter-generational equity (re: WCED, 1987; MMSD, 2002), it is certainly of considerable concern that the environment is not mentioned to any significant degree. From a geocybernetic perspective, without a viable and functional environment, as well as good management of environmental resources and services, populations within a local area cannot thrive.

The principle in regards to the Stabilization paradigm was evaluated as consistent with very weak unsustainability. This was based on an obtained GS(T) score of 0 (zero). 
This was predominantly because of the significantly negative obtained value of GS(E), as indicated in Table 8. The principle certainly emphasises the need for wealth generated from natural resource exploitation to be of benefit to a country's development. However, the lack a framework for environmental resources and services management is a fundamental weakness, for the same reasons highlighted earlier.

Even more disconcerting is the non-existence of two paradigms (Optimization and Pessimization), as indicated in Table 3. In the case of Optimization, the principle fails to meet the necessary paradigm requirements. This is because it does not provide the best course of action to contribute towards sustainable development, through the management of the coupled environment-human relationship. In point of fact, there is no mention whatsoever of the environment within the principle's construction.

Therefore, the statement of 'sustainable economic growth' within Principle 1 fails to constitute the best course of action. There is a failure to incorporate the management of the environment-human relationship. This is compounded by the non-existence of the Pessimization paradigm, which applies the precautionary principle to minimise impacts to the environment.

In very simple terms, sustainable development is the prudent use and management of economic and social development, in conjunction with the minimisation of impacts detrimental to environmental resources and services. Principle 1 fails to enforce or sufficiently encourage companies to be transparent with their measures and financial 
resources committed towards the minimisation of environmental impacts. If transparency of the economic costs and revenues brought by extraction are to hold meaning within a sustainable development context, then a commitment to meet and disclose the relevant socio-economic costs of impacts to, and management of, the environment must be included.

The failure of Principle 1 to recognise the importance of the environment, in terms of the development of a co-evolutionary relationship between the environment and humanity, consequently infers a significantly skewed anthropocentric bias of sustainable development. Furthermore, there is a lack of commitment or requirement towards real transparency within the principle, and the EITI as a whole. Specifically, in terms of management and those economic costs associated in addressing the significant detrimental impacts, which extractive industries cause to the local environment, and upon the local communities that rely on the local environment to sustain them. Therefore, this principle, which sets the tone for those to follow, indicates the EITI's approach to sustainable development is fundamentally anthropocentric and heavily focused on the economic benefits of extraction. The abject failure of the EITI to adequately ensure a commitment towards the full disclosure of resources, set aside for environmental management, and for the management and protection of the local communities' health and well-being, demonstrates a fundamental lack of, and perhaps even naive, understanding as to what should constitute sustainable development within an extractive context. 


\subsubsection{Principle 2}

Principle 2 states that: "We affirm that management of natural resource wealth for the benefit of a country's citizens is in the domain of sovereign governments to be exercised in the interests of their national development" (EITI, 2015a, p9). This principle is intended to ensure that the natural resource wealth of a country is used for the benefit of national development. The principle was determined to exhibit an Optimization-Equitization-Stabilization complex paradigm, which is consistent with weak sustainability (Table 10).

The principle recognises that the wealth created from the exploitation of natural resources should ultimately benefit the present and future generations within the country experiencing the extraction. This is why the principle exhibited the three fundamental paradigms stated. However, the principle, in practice, fails to ensure that any wealth generated is in fact used in national development, as well as for maintaining and enhancing environmental and social integrity. Such factors, explain why the paradigms evaluated for Principle 2 were determined as very weak to weak in nature (see: Tables 4, 6, 8, and 9). If the wealth generated is to the detriment, or loss, of environmental resources and services necessary for maintaining the long-term wellbeing of the inhabitants, then a more than adequate portion of this wealth should be reinvested locally to prevent or minimise such occurrences. The fact that Principle 2 does not state that the wealth generated should be re-invested to minimise impacts, explains the primary reason as to why the Pessimization paradigm was evaluated as non-existent. More specifically, the paradigm was determined as non-existent because of: (i). The failure to ensure the environment's well-being or the minimisation of 
impacts to it, particularly when gaining economic and social benefits directly from it; (ii). The failure to provide a viable environment for present and future generations, at all spatial levels within a country, meant that the precautionary principle was not evident; and (iii). The principle does not specifically state the nature of 'national development'. Therefore, this tends to infer, once again, that it is anthropocentric (predominantly economic in nature), and not as holistic as it should be, if the goal is to contribute towards sustainable development.

Whilst national development issues are principally the domain of national governments, Principle 2's construction, in geocybernetic terms, allows for the weaknesses in governance and human nature to manifest themselves to the detriment of a country's citizens. Therefore, if the intention of the principle is to ensure the proper management of a country's natural resource wealth, then there is a need to ensure this is strongly entrenched, not only in words, but also in constructive and appropriate actions.

\section{Conclusion}

The authors conducted a quantitative evaluation of the 12 principles of the Extractive Industries Transparency Initiative (EITI) through the application of a new sustainability assessment methodology - the Geocybernetic Assessment Matrix (GAM). Their results indicated that the EITI, in its current form, fundamentally fails to assist a country towards sustainable development with respect to the transparent and accountable management of its natural resource wealth. This is because of the EITI's anthropocentric nature and overemphasis on economic issues at the expense of 
environmental and social integrity. A significant risk of the current approach of the EITI is that future generations may end up with a degraded environment, which may not adequately meet their fundamental social needs. This is not an unsurprising given the EITI's roots from the anthropocentric perspective conveyed in the reports of Brundtland Commission (WCED, 1987) and the MMSD (MMSD, 2002).

The EITI, in its intention, is worthy of commendation, due to the documented abuses and corruption which can occur in developing countries with abundant natural resource wealth. However, without proper transparency and accountability as to the environmental aspects of natural resource wealth, the EITI may be considered a scheme which ultimately fails to promote and contribute towards meaningful sustainable development.

This paper supports the idea that sustainable development must be pursued through a co-evolutionary approach, with respect to the coupled dynamic relationship between the environment and humans. The EITI in its present form does not succeed in doing that. It thus needs to be revised, in order to ensure that the pathway to sustainable development is truly holistic (environmental, social and economic).

\section{Acknowledgements}

We acknowledge the support of FCT through $\mathrm{PhD}$ grant $\mathrm{PD} / \mathrm{BP} / 113742$ to Kai Whiting. 


\section{References}

Aaronson, S.A. (2011). Limited partnership: Business, government, civil society, and the public in the Extractive Industries Transparency Initiative (EITI). Public Administration and Development 31(1):50-63.

Africa Progress Panel (2013). Equity in Extractives Africa Progress Report 2013: Stewarding Africa's natural resources for all. Access: http://app-cdn.acwupload.co.uk/wpcontent/uploads/2013/08/2013_APR_Equity_in_Extractives_25062013_ENG_HR.pdf [05 April 2016]

Ataei, M., Jamshidi, M., Sereshki, F., Jalali, S. M. E. (2008). Mining method selection by AHP approach. Journal of the Southern African Institute of Mining and Metallurgy 108:741749.

Bogdanovic, D., Nikolic, D., Ilic, I. (2012). Mining method selection by integrated AHP and PROMETHEE method. Anais da Academia Brasileira de Ciências 84(1):219-233.

Cabezas, M. (2014). Tax Transparency and the Marketplace: A Pathway to State Sustainability. McGill International Journal of Sustainable Development Law and Policy 10:179.

Clark, H (2011). Avoiding the resource curse: Managing extractive Industries for Human Development. Keynote speech at the international conference on: 'Avoiding the resource curse: Managing extractive Industries for Human Development'. Ulaanbaatar, 20th October 2011. Access:

http://www.undp.org/content/undp/en/home/presscenter/speeches/2011/10/20/helen-clarkavoiding-the-resource-curse-managing-extractive-industries-for-human-development-/ [01 May 2015].

Costanza, R., Daly H.E. (1992). Natural Capital and Sustainable Development. Conservation Biology 6(1):37-46. 
Costanza, R., Graumlich, L.J., Steffen, W. (2007). Sustainability or Collapse - Lessons from Integrating the History of Humans and the Rest of Nature. In: Costanza, R., Graumlich, L.J., Steffen, W. (Eds.), Sustainability or Collapse? - An Integrated History and Future of People on Earth, MIT Press, Cambridge, Massachusetts, U.S.A, pp.3-17.

Dale, V.H., Efroymson, R.A., Kline, K.L., Davitt, M.S. (2015). A framework for selecting indicators of bioenergy sustainability. Biofuels, Bioproducts and Biorefining 9(4):435-446.

Daly, H.E. (1994). Operationalizing sustainable development by investing in natural capital. In: Jansson, A., Hammer, M,. Folke, C., Costanza, R. (Eds.), Investing in Natural Capital, Island Press, Washington DC, pp.22-37

Dearing, J.A., Dyke, J.G., Haberl, H., Hossain, S.S., Langdon, P.G., Lenton, T.M., Raworth, K., Wang, R., Zhang, K., Brown, S., Carstensen, J., Cole, M.J., Cornell, S.E., Dawson, T.P., Doncaster, C.P., Eigenbrod, F., Flörke, M., Jeffers, E., Mackay, A.W., Nykvist, B., Poppy, G.M. (2014). Safe and just operating spaces for regional social-ecological systems. Global Environmental Change 28:227-238.

Deng, X., Hu, Y., Deng, Y., Mahadevan, S. (2014). Environmental impact assessment based on D numbers. Expert Systems with Applications 41(2):635-643.

Eisenack, K., Kropp, J. (2001). Assessment of management options in marine fisheries by qualitative modelling techniques. Marine Pollution Bulletin 43(7):215-224.

Extractive Industries Transparency Initiative (EITI) (2015a). The EITI Standard. The EITI International Secretariat, Oslo, Norway. Access: https://eiti.org/document/standard [03 April 2015].

Extractive Industries Transparency Initiative (EITI) (2015b). What is the EITI? Access: https://eiti.org/eiti [01 May 2015].

Extractive Industries Transparency Initiative (EITI) (2015c). EITI Countries. Access: https://eiti.org/countries [01 May 2015]. 
Extractive Industries Transparency Initiative (EITI) (2015d). Fact Sheet The EITI International Secretariat, Oslo, Norway. Access: https://eiti.org/files/document/EITI_Factsheet_EN.pdf [01 May 2015]

Extractive Industries Transparency Initiative (EITI) (2015e). The importance of natural resources for government revenues. EITI Progress Report. Access:

http://progrep.eiti.org/2015/glance/importance-natural-resources-government-revenues [05 April 2016].

Gallopin, G. (2003) A systems approach to sustainability and sustainable development. Sustainable Development and Human Settlements Division. United Nations, Santiago, Chile.

Gholamalifard, M., Phillips, J., Jalili Ghazizade, M. (2016). Evaluation of unmitigated options for municipal waste disposal site in Tehran, Iran using an integrated assessment approach. Journal of Environmental Planning and Management. DOI: 10.1007/s13762-0160997-0

Gilbuena, R.L., Kawamura, A., Medina, R.R., Nakagawa, N. Amaguchi, H. (2013). Environmental impact assessment using a utility-based recursive evidential reasoning approach for structural flood mitigation measures in Metro Manila, Philippines. Journal of Environmental Management 131:92-102.

Great Britain (2008). Climate Change Act (2008). Stationery Office, London.

Hilson, G. (2014). The extractive industries and development in sub-Saharan Africa: An introduction. Resources Policy 40:1-3.

Huang, S., Li, X., Wang, Y. (2012). A new model of geo-environmental impact assessment of mining: a multiple-criteria assessment method integrating Fuzzy-AHP with fuzzy synthetic ranking. Environmental Earth Sciences 66(1):275-284.

Jarvie-Eggart, M.E. (Ed.) (2015). Responsible Mining: Case Studies in Managing Social \& Environmental Risks in the Developed World. Society for Mining, Metallurgy and Exploration. 
Kropp, J., Eisenack, K., Scheffran, J. (2006). Marine overexploitation: a syndrome of global change. In: Sonak, S. (Ed.), Multiple Dimensions of Global Change, TERI Press, New Delhi, pp. $257-284$.

Leventon, J., Dyer, J.C., Van Alstine, J.D. (2015). The private sector in climate governance: opportunities for climate compatible development through multilevel industry-government engagement. Journal of Cleaner Production 102:316-323

Li, W., Xie, Y., Hao, F. (2014). Applying an improved rapid impact assessment matrix method to strategic environmental assessment of urban planning in China. Environmental Impact Assessment Review 46:13-24

Lovelock, J. (1988). The ages of Gaia: a biography of our living earth. Oxford University Press, Oxford

Lucht, W. (2010). Earth system analysis and taking a crude look at the whole. In:

Schellnhuber, H.J., Molina, M., Stern, N., Huber, V., Kadner, S. (Eds.). Global sustainability: a nobel cause. Cambridge University Press, New York, pp.19-31.

Mining Association of Canada (2016). Components of TCM. Access: http://mining.ca/towards-sustainable-mining/how-tsm-works/components-tsm [05 April 2016].

MMSD (2002). Breaking New Ground: Mining, Minerals and Sustainable Development: the MMSD Project of the International Institute for Environment and Development (IIED). Earthscan, London.

Natural Resource Governance Institute (2013). Natural Resource Charter. Access: http://www.resourcegovernance.org/sites/default/files/documents/nrcj1193 natural_resource charter_19.6.14.pdf [05 April 2016]

Pastakia, C.M.R. (1998). The Rapid Impact Assessment Matrix (RIAM) - A New Tool For Environmental Impact Assessment. Access: http://www.pastakia.com/riam/publication.html [03 June 2006].

Pastakia, C.M.R., Jensen, A. (1998). The Rapid Impact Assessment Matrix (RIAM) for EIA. Environmental Impact Assessment Review 18:461-482. 
Pearce, D.W., Turner, R.K. (1990). Economics of Natural Resources and the Environment. Harvester Wheatsheaf, Hemel Hempstead.

Petschel-Held, G., Schellnhuber, H.J., Bruckner, T., Toth, F.L., Hasselmann, K. (1999). The tolerable windows approach: theoretical and methodological foundations. Climatic Change 41(3-4):303-331.

Phillips, J. (2010a). The Advancement of a Mathematical Model of Sustainable Development. Sustainability Science 5:127-142.

Phillips, J. (2010b). Evaluating the Level and Nature of Sustainable Development for a Geothermal power plant. Renewable and Sustainable Energy Review 14:2414-2425.

Phillips, J. (2011). The Conceptual Development of a Geocybernetic Relationship between Sustainable Development and Environmental Impact Assessment. Applied Geography 31:969-979.

Phillips, J. (2012). Applying a mathematical model of sustainability to the Rapid Impact Assessment Matrix evaluation of the coal mining tailings dumps in the Jiului Valley, Romania. Resources, Conservation and Recycling 63:17-25.

Phillips, J. (2016). The Geocybernetic Assessment Matrix (GAM) - A new assessment tool for evaluating the level and nature of sustainability or unsustainability. Environmental Impact Assessment Review 56:88-101.

Revenue Watch Institute (2014). Natural Resource Fund Governance: The Essentials. Access: https://eiti.org/files/Nat_Res_Funds_Governance\%20RWI\%20Vale\%20Columbia.pdf [05 April 2015]

Rockström, J., Steffen, W., Noone, K., Persson, Å., Chapin, F.S., Lambin, E.F., Lenton, T.M., Scheffer, M., Folke, C., Schellnhuber, H.J., Nykvist, B., de Wit, C.A., Hughes, T., van der Leeuw, S., Rodhe, H., Sörlin, S., Snyder, P.K., Costanza, R., Svedin, U., Falkenmark, M., Karlberg, L., Corell, R.W., Fabry, V.J., Hansen, J., Walker, B., Liverman, D., Richardson, K., Crutzen, P., Foley, J.A. (2009a). A safe operating space for humanity. Nature 461:472-475. 
Rockström, J., Steffen, W., Noone, K., Persson, Å., Chapin, F.S., Lambin, E.F., Lenton, T.M., Scheffer, M., Folke, C., Schellnhuber, H.J., Nykvist, B., de Wit, C.A., Hughes, T., van der Leeuw, S., Rodhe, H., Sörlin, S., Snyder, P.K., Costanza, R., Svedin, U., Falkenmark, M., Karlberg, L., Corell, R.W., Fabry, V.J., Hansen, J., Walker, B., Liverman, D., Richardson, K., Crutzen, P., Foley, J.A. (2009b). Planetary boundaries: exploring the safe operating space for humanity. Ecology and Society 14(2): 32. Accessed from: http://www.ecologyandsociety.org/vol14/iss2/art32/ [13 January 2010].

Schellnhuber, H.J. (1998). Part 1: Earth System Analysis - The Concept. In: Schellnhuber, H.J. and Wenzel, V. (Eds.), Earth System Analysis: Integrating Science for Sustainable development, Springer-Verlag, Berlin Heidelberg, pp.3-195.

Schellnhuber, H.J. (1999). 'Earth system' analysis and the second Copernican revolution. Nature 402, Millennium Supplement, $2^{\text {nd }}$ December 1999.

Schellnhuber, H.J. (2001). Earth System Analysis and Management. In: Ehlers E and Kraft T (Eds.), Understanding the Earth System: Compartments, Processes and Interactions, Springer-Verlag, Berlin-Heidelberg, pp.17-55.

Schellnhuber, H.J., Kropp, J. (1998). Geocybernetics: Controlling a Complex Dynamic System Under Uncertainty. Naturwissenschaften 85:411-425.

Short, C. (2014). The EITI and Transparency in the Mining Industry. The 14th Annual Victor Phillips Memorial Lecture, University of Exeter, Penryn Campus, United Kingdom, 30th October 2014.

Shroder, J.F. (2015). Progress with Afghanistan extractive industries: Will the country know resource success or failure evermore?. The Extractive Industries and Society 2(2):264-275.

Sovacool, B.K., Andrews, N. (2015). Does transparency matter? Evaluating the governance impacts of the Extractive Industries Transparency Initiative (EITI) in Azerbaijan and Liberia. Resources Policy 45:183-192.

Sturesson, A., Zobel, T. (2015). The Extractive Industries Transparency Initiative (EITI) in Uganda: Who will take the lead when the government falters?. The Extractive Industries and Society 2(1):33-45. 
Toro, J., Requena, I., Duarte, O., Zamorano, M. (2013). A qualitative method proposal to improve environmental impact assessment. Environmental Impact Assessment Review 43:920.

United Nations Development Programme (UNDP) (2012). Strategy Note. Access: http://www.undp.org/content/dam/undp/library/Poverty\%20Reduction/Extractive\%20Industri es/StrategyNote_ExtractiveSector.pdf [01 May 2015].

United Nations Development Programme (UNDP) (2015). Extractive Industries for Sustainable Development. Access:

http://www.undp.org/content/undp/en/home/ourwork/povertyreduction/focus_areas/extractive -industries.html [01 May 2015].

Wang, Y.M., Yang, J.B., Xu, D.L. (2006). Environmental impact assessment using the evidential reasoning approach. European Journal of Operational Research 174:1885-1913.

Wilson, E., Van Alstine, J. (2014). Localising transparency: Exploring EITI's contribution to sustainable development. International Institute for Environment and Development: London. Available from: http://pubs.iied.org/16555IIED.html [03 June 2015].

World Commission on Environment and Development (WCED) (1987). Our Common Future. Oxford University Press, Oxford.

World Trade Organisation (WTO) (2014). Modest trade growth anticipated for 2014 and 2015 following two year slump. Access:

https://www.wto.org/english/news_e/pres14_e/pr721_e.htm [01 May 2015].

Yang, J.B. (2001). Rule and utility based evidential reasoning approach for multiattribute decision analysis under uncertainties. European Journal of Operational Research 131:31-61.

Yang, J.B., Singh, M.G. (1994). An evidential reasoning approach for multiple-attribute decision making with uncertainty. IEEE Transactions on Systems, Man and Cybernetics, 24(1):1-18. 


\section{Appendix}

Table A1 The 12 principles of the EITI (EITI, 2015a, p9).

\section{EITI Principles}

1. We share a belief that the prudent use of natural resource wealth should be an important engine for sustainable economic growth that contributes to sustainable development and poverty reduction, but if not managed properly, can create negative economic and social impacts.

2. We affirm that management of natural resource wealth for the benefit of a country's citizens is in the domain of sovereign governments to be exercised in the interests of their national development.

3. We recognise that the benefits of resource extraction occur as revenue streams over many years and can be highly price dependent.

4. We recognise that a public understanding of government revenues and expenditure over time could help public debate and inform choice of appropriate and realistic options for sustainable development.

5. We underline the importance of transparency by governments and companies in the extractive industries and the need to enhance public financial management and accountability.

6. We recognise that achievement of greater transparency must be set in the context of respect for contracts and laws.

7. We recognise the enhanced environment for domestic and foreign direct investment that financial transparency may bring.

8. We believe in the principle and practice of accountability by government to all citizens for the stewardship of revenue streams and public expenditure.

9. We are committed to encouraging high standards of transparency and accountability in public life, government operations and in business.

10. We believe that a broadly consistent and workable approach to the disclosure of payments and revenues is required, which is simple to undertake and to use.

11. We believe that payments' disclosure in a given country should involve all extractive industry companies operating in that country.

12. In seeking solutions, we believe that all stakeholders have important and relevant contributions to make including governments and their agencies, extractive industry companies, service companies, multilateral organisations, financial organisations, investors and non-governmental organisations. 
Table A2 GAM evaluation of GS(E), GS(S) and GS(Ec) values for the determined EITI principles with respect to the Standardization paradigm.

\begin{tabular}{|c|c|c|c|c|c|c|c|c|c|c|c|c|c|c|c|c|c|c|}
\hline \multirow{3}{*}{ EITI Principles } & \multicolumn{18}{|c|}{ Geocybernetic Paradigm - Standardization } \\
\hline & \multicolumn{6}{|c|}{ Environment } & \multicolumn{6}{|c|}{ Social } & \multicolumn{6}{|c|}{ Economic } \\
\hline & GS(E) & A1 & $\mathrm{A} 2$ & $\mathrm{~A} 3$ & $\mathrm{~B} 1$ & $\mathrm{~B} 2$ & $\mathrm{GS}(\mathrm{S})$ & $\mathrm{A} 1$ & A2 & A3 & $\mathrm{B} 1$ & $\mathrm{~B} 2$ & $\mathrm{GS}(\mathrm{Ec})$ & A1 & A2 & A3 & B1 & $\mathrm{B} 2$ \\
\hline $\begin{array}{l}\text { 4. We recognise that a public understanding of government revenues and expenditure over time } \\
\text { could help public debate and inform choice of appropriate and realistic options for sustainable } \\
\text { development. }\end{array}$ & 32 & 2 & 1 & 2 & 4 & 4 & 144 & 3 & 2 & 3 & 4 & 4 & 216 & 3 & 3 & 3 & 4 & 4 \\
\hline $\begin{array}{l}\text { 5. We underline the importance of transparency by governments and companies in the } \\
\text { extractive industries and the need to enhance public financial management and accountability. }\end{array}$ & 0 & 0 & 1 & 0 & 4 & 4 & 216 & 3 & 3 & 3 & 4 & 4 & 216 & 3 & 3 & 3 & 4 & 4 \\
\hline $\begin{array}{l}\text { 6. We recognise that achievement of greater transparency must be set in the context of respect } \\
\text { for contracts and laws. }\end{array}$ & 0 & 0 & 1 & 0 & 4 & 4 & 216 & 3 & 3 & 3 & 4 & 4 & 144 & 3 & 2 & 3 & 4 & 4 \\
\hline $\begin{array}{l}\text { 11. We believe that payments' disclosure in a given country should involve all extractive } \\
\text { industry companies operating in that country. }\end{array}$ & 0 & 0 & 1 & 0 & 4 & 4 & 216 & 3 & 3 & 3 & 4 & 4 & 216 & 3 & 3 & 3 & 4 & 4 \\
\hline
\end{tabular}


Table A3 GAM evaluation of GS(E), GS(S) and GS(Ec) values for the determined EITI principles with respect to the Optimization paradigm.

\begin{tabular}{|c|c|c|c|c|c|c|c|c|c|c|c|c|c|c|c|c|c|c|}
\hline \multirow{3}{*}{ EITI Principles } & \multicolumn{18}{|c|}{ Geocybernetic Paradigm - Optimization } \\
\hline & \multicolumn{6}{|c|}{ Environment } & \multicolumn{6}{|c|}{ Social } & \multicolumn{6}{|c|}{ Economic } \\
\hline & GS(E) & A1 & $\mathrm{A} 2$ & $\mathrm{~A} 3$ & $\overline{\mathrm{B} 1}$ & $\mathrm{~B} 2$ & GS(S) & $\overline{\mathrm{A} 1}$ & A2 & A3 & $\mathrm{B} 1$ & $\mathrm{~B} 2$ & GS(Ec) & A1 & A2 & $\overline{\mathrm{A} 3}$ & $\mathrm{~B} 1$ & $\bar{B} 2$ \\
\hline $\begin{array}{l}\text { 2. We affirm that management of natural resource wealth for the benefit of a country's citizens } \\
\text { is in the domain of sovereign governments to be exercised in the interests of their national } \\
\text { development. }\end{array}$ & 48 & 3 & 1 & 2 & 4 & 4 & 216 & 3 & 3 & 3 & 4 & 4 & 216 & 3 & 3 & 3 & 4 & 4 \\
\hline $\begin{array}{l}\text { 4. We recognise that a public understanding of government revenues and expenditure over time } \\
\text { could help public debate and inform choice of appropriate and realistic options for sustainable } \\
\text { development. }\end{array}$ & 24 & 3 & 1 & 1 & 4 & 4 & 216 & 3 & 3 & 3 & 4 & 4 & 216 & 3 & 3 & 3 & 4 & 4 \\
\hline $\begin{array}{l}\text { 5. We underline the importance of transparency by governments and companies in the } \\
\text { extractive industries and the need to enhance public financial management and accountability. }\end{array}$ & 0 & 2 & 1 & 0 & 4 & 4 & 216 & 3 & 3 & 3 & 4 & 4 & 216 & 3 & 3 & 3 & 4 & 4 \\
\hline $\begin{array}{l}\text { 6. We recognise that achievement of greater transparency must be set in the context of respect } \\
\text { for contracts and laws. }\end{array}$ & 0 & 3 & 1 & 0 & 4 & 4 & 216 & 3 & 3 & 3 & 4 & 4 & 216 & 3 & 3 & 3 & 4 & 4 \\
\hline $\begin{array}{l}\text { 10. We believe that a broadly consistent and workable approach to the disclosure of payments } \\
\text { and revenues is required, which is simple to undertake and to use. }\end{array}$ & -48 & 3 & 1 & -2 & 4 & 4 & 216 & 3 & 3 & 3 & 4 & 4 & 216 & 3 & 3 & 3 & 4 & 4 \\
\hline $\begin{array}{l}\text { 11. We believe that payments' disclosure in a given country should involve all extractive } \\
\text { industry companies operating in that country. }\end{array}$ & -96 & 3 & 2 & -2 & 4 & 4 & 216 & 3 & 3 & 3 & 4 & 4 & 216 & 3 & 3 & 3 & 4 & 4 \\
\hline $\begin{array}{l}\text { 12. In seeking solutions, we believe that all stakeholders have important and relevant } \\
\text { contributions to make - including governments and their agencies, extractive industry } \\
\text { companies, service companies, multilateral organisations, financial organisations, investors } \\
\text { and non-governmental organisations. }\end{array}$ & 72 & 3 & 3 & 1 & 4 & 4 & 216 & 3 & 3 & 3 & 4 & 4 & 216 & 3 & 3 & 3 & 4 & 4 \\
\hline
\end{tabular}


Table A4 GAM evaluation of GS(E), GS(S) and GS(Ec) values for the determined EITI principles with respect to the Pessimization paradigm.

\begin{tabular}{|c|c|c|c|c|c|c|c|c|c|c|c|c|c|c|c|c|c|c|}
\hline \multirow{3}{*}{ EITI Principles } & \multicolumn{18}{|c|}{ Geocybernetic Paradigm - Pessimization } \\
\hline & \multicolumn{6}{|c|}{ Environment } & \multicolumn{6}{|c|}{ Social } & \multicolumn{6}{|c|}{ Economic } \\
\hline & GS(E) & A1 & $\mathrm{A} 2$ & A3 & B1 & B2 & GS(S) & A1 & A2 & $\mathrm{A} 3$ & B1 & $\mathrm{B} 2$ & $\mathrm{GS}(\mathrm{Ec})$ & $\mathrm{A} 1$ & A2 & A3 & $\mathrm{B} 1$ & B2 \\
\hline $\begin{array}{l}\text { 4. We recognise that a public understanding of government revenues and expenditure over time } \\
\text { could help public debate and inform choice of appropriate and realistic options for sustainable } \\
\text { development. }\end{array}$ & -72 & 3 & 1 & -3 & 4 & 4 & 96 & 3 & 2 & 2 & 4 & 4 & 96 & 3 & 2 & 2 & 4 & 4 \\
\hline $\begin{array}{l}\text { 6. We recognise that achievement of greater transparency must be set in the context of respect } \\
\text { for contracts and laws. }\end{array}$ & 24 & 3 & 1 & 1 & 4 & 4 & 216 & 3 & 3 & 3 & 4 & 4 & 216 & 3 & 3 & 3 & 4 & 4 \\
\hline
\end{tabular}


Table A5 GAM evaluation of GS(E), GS(S) and GS(Ec) values for the determined EITI principles with respect to the Equitization paradigm.

\begin{tabular}{|c|c|c|c|c|c|c|c|c|c|c|c|c|c|c|c|c|c|c|}
\hline \multirow{3}{*}{ EITI Principles } & \multicolumn{18}{|c|}{ Geocybernetic Paradigm - Equitization } \\
\hline & \multicolumn{6}{|c|}{ Environment } & \multicolumn{6}{|c|}{ Social } & \multicolumn{6}{|c|}{ Economic } \\
\hline & GS(E) & $\mathrm{A} 1$ & $\mathrm{~A} 2$ & $\mathrm{~A} 3$ & B1 & B2 & GS(S) & $\mathrm{A} 1$ & A2 & A3 & $\mathrm{B} 1$ & $\mathrm{~B} 2$ & $\mathrm{GS}(\mathrm{Ec})$ & $\mathrm{A} 1$ & A2 & A3 & B1 & $\mathrm{B} 2$ \\
\hline $\begin{array}{l}\text { 1. We share a belief that the prudent use of natural resource wealth should be an important } \\
\text { engine for sustainable economic growth that contributes to sustainable development and } \\
\text { poverty reduction, but if not managed properly, can create negative economic and social } \\
\text { impacts. }\end{array}$ & -96 & 3 & 2 & -2 & 4 & 4 & 216 & 3 & 3 & 3 & 4 & 4 & 216 & 3 & 3 & 3 & 4 & 4 \\
\hline $\begin{array}{l}\text { 2. We affirm that management of natural resource wealth for the benefit of a country's citizens } \\
\text { is in the domain of sovereign governments to be exercised in the interests of their national } \\
\text { development. }\end{array}$ & -144 & 3 & 3 & -2 & 4 & 4 & 216 & 3 & 3 & 3 & 4 & 4 & 216 & 3 & 3 & 3 & 4 & 4 \\
\hline $\begin{array}{l}\text { 4. We recognise that a public understanding of government revenues and expenditure over time } \\
\text { could help public debate and inform choice of appropriate and realistic options for sustainable } \\
\text { development. }\end{array}$ & -72 & 3 & 1 & -3 & 4 & 4 & 216 & 3 & 3 & 3 & 4 & 4 & 216 & 3 & 3 & 3 & 4 & 4 \\
\hline $\begin{array}{l}\text { 6. We recognise that achievement of greater transparency must be set in the context of respect } \\
\text { for contracts and laws. }\end{array}$ & -72 & 3 & 1 & -3 & 4 & 4 & 216 & 3 & 3 & 3 & 4 & 4 & 144 & 3 & 3 & 2 & 4 & 4 \\
\hline $\begin{array}{l}\text { 7. We recognise the enhanced environment for domestic and foreign direct investment that } \\
\text { financial transparency may bring. }\end{array}$ & -81 & 3 & 1 & -3 & 5 & 4 & 216 & 3 & 3 & 3 & 4 & 4 & 243 & 3 & 3 & 3 & 5 & 4 \\
\hline
\end{tabular}


Table A6 GAM evaluation of GS(E), GS(S) and GS(Ec) values for the determined EITI principles with respect to the Stabilization paradigm

\begin{tabular}{|c|c|c|c|c|c|c|c|c|c|c|c|c|c|c|c|c|c|c|}
\hline \multirow{3}{*}{ EITI Principles } & \multicolumn{18}{|c|}{ Geocybernetic Paradigm - Stabilization } \\
\hline & \multicolumn{6}{|c|}{ Environment } & \multicolumn{6}{|c|}{ Social } & \multicolumn{6}{|c|}{ Economic } \\
\hline & $\mathrm{GS}(\mathrm{E})$ & $\mathrm{A} 1$ & $\mathrm{~A} 2$ & A3 & $\mathrm{B} 1$ & $\mathrm{~B} 2$ & GS(S) & A1 & A2 & $\mathrm{A} 3$ & B1 & B2 & $\mathrm{GS}(\mathrm{Ec})$ & A1 & $\mathrm{A} 2$ & $\mathrm{~A} 3$ & B1 & $\mathrm{B} 2$ \\
\hline $\begin{array}{l}\text { 1. We share a belief that the prudent use of natural resource wealth should be an important } \\
\text { engine for sustainable economic growth that contributes to sustainable development and } \\
\text { poverty reduction, but if not managed properly, can create negative economic and social } \\
\text { impacts. }\end{array}$ & -216 & 3 & 3 & -3 & 4 & 4 & 216 & 3 & 3 & 3 & 4 & 4 & 216 & 3 & 3 & 3 & 4 & 4 \\
\hline $\begin{array}{l}\text { 2. We affirm that management of natural resource wealth for the benefit of a country's citizens } \\
\text { is in the domain of sovereign governments to be exercised in the interests of their national } \\
\text { development. }\end{array}$ & -216 & 3 & 3 & -3 & 4 & 4 & 216 & 3 & 3 & 3 & 4 & 4 & 216 & 3 & 3 & 3 & 4 & 4 \\
\hline $\begin{array}{l}\text { 4. We recognise that a public understanding of government revenues and expenditure over time } \\
\text { could help public debate and inform choice of appropriate and realistic options for sustainable } \\
\text { development. }\end{array}$ & -144 & 3 & 2 & -3 & 4 & 4 & 216 & 3 & 3 & 3 & 4 & 4 & 216 & 3 & 3 & 3 & 4 & 4 \\
\hline $\begin{array}{l}\text { 6. We recognise that achievement of greater transparency must be set in the context of respect } \\
\text { for contracts and laws. }\end{array}$ & -216 & 3 & 3 & -3 & 4 & 4 & 216 & 3 & 3 & 3 & 4 & 4 & 216 & 3 & 3 & 3 & 4 & 4 \\
\hline $\begin{array}{l}\text { 7. We recognise the enhanced environment for domestic and foreign direct investment that } \\
\text { financial transparency may bring. }\end{array}$ & 0 & 0 & 1 & 0 & 4 & 4 & 16 & 2 & 1 & 1 & 4 & 4 & 144 & 3 & 3 & 2 & 4 & 4 \\
\hline $\begin{array}{l}\text { 8. We believe in the principle and practice of accountability by government to all citizens for } \\
\text { the stewardship of revenue streams and public expenditure. }\end{array}$ & -48 & 3 & 1 & -2 & 4 & 4 & 216 & 3 & 3 & 3 & 4 & 4 & 216 & 3 & 3 & 3 & 4 & 4 \\
\hline $\begin{array}{l}\text { 9. We are committed to encouraging high standards of transparency and accountability in } \\
\text { public life, government operations and in business. }\end{array}$ & 72 & 3 & 3 & 1 & 4 & 4 & 216 & 3 & 3 & 3 & 4 & 4 & 216 & 3 & 3 & 3 & 4 & 4 \\
\hline $\begin{array}{l}\text { 10. We believe that a broadly consistent and workable approach to the disclosure of payments } \\
\text { and revenues is required, which is simple to undertake and to use. }\end{array}$ & -144 & 3 & 3 & -2 & 4 & 4 & 216 & 3 & 3 & 3 & 4 & 4 & 216 & 3 & 3 & 3 & 4 & 4 \\
\hline $\begin{array}{l}\text { 11. We believe that payments' disclosure in a given country should involve all extractive } \\
\text { industry companies operating in that country. }\end{array}$ & -144 & 3 & 3 & -2 & 4 & 4 & 216 & 3 & 3 & 3 & 4 & 4 & 216 & 3 & 3 & 3 & 4 & 4 \\
\hline $\begin{array}{l}\text { 12. In seeking solutions, we believe that all stakeholders have important and relevant } \\
\text { contributions to make - including governments and their agencies, extractive industry } \\
\text { companies, service companies, multilateral organisations, financial organisations, investors } \\
\text { and non-governmental organisations. }\end{array}$ & 216 & 3 & 3 & 3 & 4 & 4 & 216 & 3 & 3 & 3 & 4 & 4 & 216 & 3 & 3 & 3 & 4 & 4 \\
\hline
\end{tabular}

